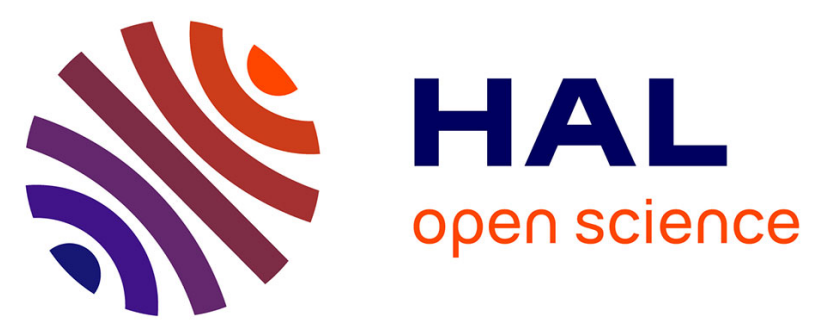

\title{
Influence of incision rate, rock strength, and bedload supply on bedrock river gradients and valley-flat widths: Field-based evidence and calibrations from western Alpine rivers (southeast France)
}

Gilles Y. Brocard, Pieter van Der Beek

\section{To cite this version:}

Gilles Y. Brocard, Pieter van Der Beek. Influence of incision rate, rock strength, and bedload supply on bedrock river gradients and valley-flat widths: Field-based evidence and calibrations from western Alpine rivers (southeast France). Willett, S.D., Hovius, N., Brandon, M.T., and Fisher, D. Tectonics, Climate, and Landscape Evolution, Geological Society of America, pp.101-126, 2006, Geological Society of America Special Paper 398, 10.1130/2006.2398(07) . hal-00083659

\section{HAL Id: hal-00083659 \\ https://hal.science/hal-00083659}

Submitted on 3 Jul 2006

HAL is a multi-disciplinary open access archive for the deposit and dissemination of scientific research documents, whether they are published or not. The documents may come from teaching and research institutions in France or abroad, or from public or private research centers.
L'archive ouverte pluridisciplinaire HAL, est destinée au dépôt et à la diffusion de documents scientifiques de niveau recherche, publiés ou non, émanant des établissements d'enseignement et de recherche français ou étrangers, des laboratoires publics ou privés. 
Influence of incision rate, rock strength and bedload supply on bedrock river gradients and valley-flat widths:

\title{
Field-based evidence and calibrations from western Alpine rivers (SE France).
}

\author{
G.Y. Brocard*, P.A. van der Beek \\ Laboratoire de Géodynamique des Chaînes Alpines, Université Joseph Fourier, 38041 \\ Grenoble, France \\ * Now at: Department of Geology and Geophysics, University of Minnesota, MN 55455, \\ Minneapolis, USA
}

Submitted to: Geol. Soc. Am. Spec. Paper

"Tectonics, Climate and Landscape Evolution"

S.D. Willett, N. Hovius, M.T. Brandon and D. Fisher, eds. 


\begin{abstract}
Several process-based models of river incision have been proposed in recent years that attempt to describe fluvial landform development. Although some field tests have been performed, more data are required to test the ability of these models to predict the observed evolution of fluvial landforms. We have investigated several tens of rivers located in the French Western Alps that flow across folded sedimentary rocks with strongly contrasting rock strengths. These rivers record significant variations in some of the parameters controlling river incision, notably bedrock lithology, stream power, incision rate and sediment flux, potentially allowing discrimination between existing models. Variations in incision rates are driven by variations in the amount of disequilibrium introduced in the river profiles during the Last Glaciation. We use diagnostic indices for transport- and detachment-limited conditions that are the channel morphology, the occurrence of lithogenic knickpoints, the continuity of alluvial and bedrock reaches and the slope-area scaling of the river long-profile. We observe transitions from detachment-limited to transport-limited conditions with increasing discharge/drainage area and decreasing incision rate. Bedrock strength influences the location of the transition predictably. The formation of transport-limited rivers coincides with the development of a valley flat wider than the active channel, which accommodates variations in bedrock strength, stream power and incision rate along the transport-limited reaches. We propose and calibrate a model for the development of valley flats along transport-limited rivers and explore some properties of landscape development in mountain ranges controlled by transport-limited rivers.
\end{abstract}




\section{INTRODUCTION}

The relief of active mountain belts is the result of the competition between rock uplift and erosion. In non-glaciated areas, the erosion system is controlled by river incision, as streams maintain both the transport of debris generated on mountain slopes and the incision of the bedrock (e.g., Burbank et al., 1996; Benda and Dunne, 1997). Through incision and clearing of colluvium, rivers control the steepness of valley flanks and thus regulate erosion on catchment slopes. At the mountain-range scale, river long profiles control the bulk elevation of the orogen (e.g., Whipple et al., 1999). As the capacity of a river to incise bedrock and transport sediments depends on its gradient, a positive feedback exists between rock uplift and river incision. Relief is therefore thought to evolve toward a dynamic equilibrium between uplift and erosion; such equilibrium is often assumed and used in neotectonic studies to infer uplift rates from river incision rate measurements, which can be compared with uplift rates obtained by other methods (e.g. Personius, 1995; Burbank et al., 1996; Harbor, 1998; Lavé and Avouac, 2001; Pazzaglia and Brandon, 2001).

The European Alps are a slowly growing orogen, and most of the present-day pattern of uplift is poorly constrained. Our study of fluvial forms in the Western Alps therefore started as an assessment of the ability of such analyses to provide useful information on neotectonic activity. Large glaciers have developed in the Alps during the Quaternary glaciations. They have formed in the highest parts of the range and have spread as far as the foreland. A study of river long-profile development in the western Alps has shown that river incision is mostly triggered by the restoration of graded profiles in rivers that have been severely glacially disturbed (Brocard, 2002; Brocard et al., 2003). Tectonically driven incision is therefore outstripped by the post-glacial relaxation of the fluvial system in this area, and the extraction of a neotectonic signature would require highly accurate data on post-glacial re-equilibration. The southwestern-most part of the Alps, however, has not been occupied by ice. The relief of this area is thought to be close to equilibrium, since river incision rates (Brocard et al., 2003), present-day erosion rates (e.g. Alary, 1998) and thermochronologically derived long-term denudation rates (Seward et al., 1999; Bigot-Cormier et al., 2000; Bernet et al., 2001) are of the same order of magnitude.

This paper presents the equilibrium forms developed by rivers located in a non-glaciated portion of the western Alps (Fig. 1) and their evolution as a function of bedrock erodibility, incision rate, stream power and sediment flux. Two major and potentially useful markers are 
described: the river long profile and the valley flat. These features are expected to exhibit detectable variations due to tectonic forcing.

Bedrock river long profiles have received considerable attention in the last decade, because they control the overall relief of mountain ranges. In many numerical models of landscape evolution, the "Stream Power" incision law (e.g., Howard et al., 1994; Whipple and Tucker, 1999) is used to link river incision rate $(\dot{E})$ to drainage area $(A)$ and gradient $(S)$ :

$$
\dot{E}=K_{d} A^{m_{d}} S^{n_{d}}
$$

where $K_{d}$ is an erosional efficiency factor with dimension $\left[\mathrm{L}^{\left(1-2 m_{d}\right)} \mathrm{T}^{-1}\right]$ and $m_{d}$ and $n_{d}$ are nondimensional exponents. If relief is in dynamic equilibrium, the uplift rate $(\dot{U})$ can be substituted for the incision rate $(\dot{E})$. The stream power law is convenient because it is a process-based erosion law that relates incision to measurable geomorphic parameters. The erosion of bedrock is considered to proceed by abrasion, plucking and cavitation; the values for the exponents in the law should be determined by the dominant process (e.g., Whipple et al., 2000). River incision in such a detachment-limited model is controlled by the erodibility of the bedrock through the parameter $K_{d}$. This simple law has been used extensively, with some authors even inferring patterns of crustal deformation from river profiles (e.g., Kirby and Whipple, 2001; Finlayson et al., 2002).

However, recent work has highlighted the strong influence of bedload transport on incision rate (Sklar and Dietrich, 1998, 2001) and its potential effects on river long-profile development (Howard et al., 1994; Sklar and Dietrich, 1998; Whipple and Tucker, 2002). Various models of river incision have been proposed that incorporate bedload control to some degree (e.g., Beaumont et al., 1992; Sklar and Dietrich, 1998). These models predict progressive transitions from detachment-limited rivers that are well described by the stream power law toward transport-limited rivers, the incision of which is controlled by the bedload.

A transport-limited incision rule can be derived in a form similar to the detachmentlimited stream power law by stating that volumetric transport capacity $\left(Q_{e q}\right)$ is a function of stream power, sediment flux is equal to carrying capacity, and incision or deposition rate equals the downstream divergence of sediment flux (e.g., Willgoose et al., 1991): 


$$
\begin{gathered}
Q_{e q}=K_{t} A^{m t^{\prime}} S^{n t} \\
E=\frac{1}{W_{c}} \frac{d}{d x} Q_{e q}
\end{gathered}
$$

where $K_{t}$ is a sediment transport coefficient $\left[\mathrm{L}^{\left(3-2 m_{t}{ }^{\prime}\right)} \mathrm{T}^{-1}\right], m_{t}$ ' and $n_{t}$ are area and slope exponents as in (1), and $W_{c}$ is bankfull channel width. By using the well-known relationships between drainage area and channel length $x$ (e.g., Hack, 1957), $A=k_{a} x^{h}$, and between channel width $W_{c}$ and drainage area (e.g., Leopold and Maddock, 1953), $W_{c}=K_{c} A^{c}$, a power-law solution for river incision can be found:

$$
\dot{E}=K_{t} A^{\left(m_{t}-1\right)} S^{n_{t}}
$$

Where $m_{t}=m_{t}{ }^{\prime}-c$. Rivers are expected to behave according to one of these end-member cases (detachment-limited; Equation 1 or transport-limited; Equation 2) or as a hybrid between the two.

Unlike variations in channel profiles or channel width, the potential significance of variations in valley-flat width has received much less attention up to now (notable exceptions being Harbor, 1998; Hancock and Anderson, 2002; Snyder et al., 2003a; Tomkin et al., 2003). The widespread development of valley flats in our study area led us to explore the factors that control valley-flat widths, with the aim of extracting possible tectonic forcing.

In the following, we first present the tectonic, climatic and lithologic variables that control the incision pattern and fluvial landform development along the studied rivers. Second, we present the diagnostic indices we have used to infer whether river segments are detachmentor transport-limited. These indices are: (1) the channel-bed morphology, (2) the sensitivity of river gradients to bedrock erodibility, (3) the continuity and parallelism of alluvial and bedrock reaches, and (4) the slope-area scaling behavior of the river segments. Third, we investigate the properties of the transition from detachment-limited to transport-limited reaches. We cannot resolve the form of the transition with sufficient resolution to discriminate between simple stream power models and more elaborate sediment-flux dependent incision models. However, our study area is ideally suited to study the influence of bedrock erodibility and of incision rate on the location of this transition. Fourth, the valley-flat data are exposed. We describe the main physical characteristics of valley flats in our study area. We then explore the influence of bedrock erodibility, river discharge, and incision rate on the valley- 
flat width. We propose a theoretical framework to account for valley-flat development and test its ability to explain the data. Finally, we discuss the overall accordance between the field data and the available river incision models and evaluate what values for model parameters are implied by our data. We explore what the response of a mixed transport- and detachmentlimited river system to uplift rate variations will be and use field examples to demonstrate the implications of such a system for drainage stability.

\section{THE WESTERN ALPS: TECTONICS AND MORPHOLOGY}

The western Alps are a collisional orogen that started to emerge above sea level since Eocene times. At the mountain-belt scale, two main units are distinguished (Fig. 1): the Internal or Penninic Alps are composed of highly deformed and metamorphosed rocks of oceanic and continental origin. This unit was deformed and thrusted onto the European passive margin before the Miocene along the Penninic frontal thrust (e.g., Schmid and Kissling, 2000), which currently acts as an extensional detachment fault (Tricart et al., 2001). The External Alps are much less deformed. They were incorporated within the orogenic wedge during the MioPliocene and are composed of crystalline basement blocks adjacent to foreland fold-and-thrust belts. Our study area is located within the External Alps; it is composed of several tectonic units of the former European passive margin that were inverted during the Pyrenean (Upper Cretaceous) and Alpine (Eocene and Miocene) orogenies. Tectonic units include the Paleozoic basement of the Pelvoux External Crystalline Massif, composed of high-grade metamorphic and igneous rocks, overlain by a Mesozoic sequence of marly and calcareous sediments that are largely detached from the basement by a Triassic evaporate layer. The Mesozoic sequence is locally overlain by remnants of the Cenozoic foreland basin, incorporated into the thrust slices by the outward propagation of the orogenic front.

The crystalline Pelvoux Massif is much higher than the surrounding "Subalpine" massifs of the foreland fold-and-thrust belt; most of its peaks are above $3000 \mathrm{~m}$ in elevation, and several summits reach $4000 \mathrm{~m}$ (Fig. 2). Valleys in the Pelvoux Massif have conspicuously glacial forms; they are very deep (typically $2500 \mathrm{~m}$ ) with very steep sidewalls. To the West, thick limestone series have produced large gently folded karstic plateaus: the Vercors (peak elevation $2341 \mathrm{~m}$ ) and Devoluy (2790 m) massifs. Elsewhere, relief is more subdued, with a suite of marly basins separated by thin crests of limestone that stand $\sim 1000 \mathrm{~m}$ above the surrounding valley floors. 
The study area has a temperate mid-latitude climate; mean annual precipitation is around $1000 \mathrm{~mm} \mathrm{y}^{-1}$ and is evenly distributed throughout the year. To the South, the climate tends toward the Mediterranean type, with dry hot summers, heavy rains in autumn, and damp and fresh winters. To the East, it becomes mountainous with highest discharges during the spring due to snowmelt. To the North, the climate becomes temperate marine with an increasing influence of Atlantic winds.

\section{Tectonic and climatic forcing of river incision in the western Alps}

During the Quaternary, the driving processes of river incision in the western Alps were continuing rock uplift as well as climatic forcing. The Alps are nowadays moderately active: both long- and short-term uplift and denudation rates are typically in the order of 0.5-1.0 mm $\mathrm{y}^{-1}$ in the western part of the orogen (e.g. Martinod et al., 1996: Jouanne et al., 1998; BigotCormier et al., 2000; Bernet et al., 2001; Tricart et al., 2001). The overall concordance of present-day rock uplift rates, short-term river incision rates and long-term denudation rates has been interpreted as indicating that the western Alpine relief may tend toward dynamic equilibrium between uplift and erosion (Bernet et al., 2001; Brocard et al., 2003).

During the Quaternary, the Alps experienced widespread glaciations that repeatedly reshaped the landscape. The Alpine glaciers were fed by snowfields located within the Internal Alps, spilled across the External Alps and spread far onto the northwestern European foreland (Montjuvent, 1978; Mandier, 1984). The ice streams oversteepened the valley long profiles downstream of confluence steps and riegels, and carved long and deep troughs into the softer rock beds. Since the end of the Last Glaciation, the rivers that flow along these reaches tend to restore graded long profiles. This is achieved by filling of the glacial troughs with sediments and by incising the oversteepened reaches. Most of the glacial trough lakes have been quickly filled with suspended river load (e.g., Chapron, 1999). In many places, however, rivers are still aggrading, as their gradients are not yet steep enough to allow the bedload to overpass the glacial troughs. The incision of oversteepened reaches remains active, as graded profiles have not been achieved even along the largest streams.

The study area (Figs. 1 and 2) covers a bulk area of $5500 \mathrm{~km}^{2}$. Our morphological analysis is focused on three medium-size rivers and 42 smaller streams (Fig. 2b). The main rivers are the Drac, the Drôme and the Buëch; morphometric properties for their catchments are given in

Table 1. These rivers preserve numerous terraces that have been dated using cosmogenic ${ }^{10} \mathrm{Be}$ 
to infer incision rates (Brocard et al., 2003; cf. next section). The Drac River drains the resistant crystalline rocks (granites, gneisses and amphibolites) of the Pelvoux Massif in its headwaters before flowing northwestward into an isoclinal structure of Mesozoic sediments. The Buëch and Drôme rivers, as well as the smaller investigated rivers, flow exclusively within the Mesozoic sedimentary cover through interference structures of Late Cretaceous to Miocene folds. Their bedrock (Fig. 3) is composed of very thick (up to $2000 \mathrm{~m}$ ) marly formations, interbedded with thin (20 to $80 \mathrm{~m}$ ) levels of highly resistant massive limestone, in addition to thicker (up to $300 \mathrm{~m}$ ) but softer rhythmic successions of marl and marly limestone.

Seismic activity, relatively insignificant in most of the Western Alps, is practically absent in the study area (see, for instance, http://sismalp.obs.ujf-grenoble.fr/sismalpuk.html). No post-Miocene deformation features have been identified with certainty so far. However, the highest terrace level of the Drôme River is slightly bent and upwarped in the downstream vicinity of the Subalpine Front (Fig. 2a), the main frontal trust of the Alps during the Miocene (Brocard, 2002). The terrace deformation suggests that the frontal thrust has maintained a low level of activity throughout the Plio-Pleistocene. No differential uplift has been identified upstream of the Subalpine Front within the fold-and-thrust belt, where most of the studied rivers are located. We thus assume that the tectonically-driven component of river incision is constant throughout the study area.

In the investigated area, glaciers coming from the Internal Alps during glacial periods were not large enough to reach the foreland and were diverted by north-south trending structures (Fig. 2a). Their influence therefore decreases westward. To the East, rivers like the Drac and its tributaries were partly invaded by ice streams that strongly modified their long profile (Montjuvent, 1973; Brocard et al., 2003). To the West, valleys remained ice-free during glaciations. The combination of a constant and relatively slow, tectonically-driven component to river incision, together with a rapid and unevenly distributed, climaticallydriven component allows observing a wide range of incision rates throughout an area that is lithologically, tectonically and climatically homogeneous.

\section{Incision rate data}

Incision rates have been measured along the Drac and Buëch rivers, which have constructed numerous terraces during the Pleistocene. Of these, the Drac River was most strongly affected by glacial advances, during which a series of glaciers dammed the river valley. Fill terraces 
were built upstream from these ice-dams (Montjuvent, 1973). Since the Last Glacial Maximum, the Drac River has entrenched the fill deposits and underlying bedrock, carving out cut-fill and strath terraces. Cosmogenic ${ }^{10} \mathrm{Be}$ dating of these terraces (Brocard et al., 2003) has shown that incision is controlled by retreating knickpoints: at a site located $\sim 15 \mathrm{~km}$ upstream of the major glacier dam, incision began several thousand years after the inception of glacial retreat and occurred at a rate greater than $60 \mathrm{~mm} \mathrm{y}^{-1}$ during less than $5 \mathrm{ky}$ before dropping to $8-11 \mathrm{~mm} \mathrm{y}^{-1}$ over the last $7 \mathrm{ky}$. A degraded unstable knickpoint occurs in the present-day long profile of the Drac River (cf. next section); this knickpoint is interpreted as being the remant of the initial glacially oversteepened reach that has migrated $\sim 55 \mathrm{~km}$ upstream during Holocene times. Incision rates downstream of this knickpoint are significantly higher $\left(7.4 \pm 1.0 \mathrm{~mm} \mathrm{y}^{-1}\right)$ than upstream $\left(4.6 \pm 0.7 \mathrm{~mm} \mathrm{y}^{-1}\right)$.

The Buëch represents an intermediate type of river, whose regime and bedload characteristics have been modified by the meltwater contribution of large glaciers located in its upper catchment (Brocard et al., 2003). The glacially increased discharge and sediment flux led to the formation of paired terraces (Mandier, 1984). The Buëch River preserves three terrace levels whose treads stand 20,80, and $190 \mathrm{~m}$ above the present-day valley floor, respectively. ${ }^{10} \mathrm{Be}$ dating of these terraces shows that the river's incision rate is roughly constant at $0.8 \mathrm{~mm} \mathrm{y}^{-1}$ when integrated over periods longer than the mean duration of the glaciations (Brocard et al., 2003).

The Drôme River catchment and the many smaller river catchments analysed here have never been glaciated. The glacial-interglacial climatic fluctuations, however, significantly modified their regime and triggered the formation of paired strath terraces along the largest streams (e.g., Drôme, Bès, Gervanne). The treads of these terraces are degraded, which precludes their dating using cosmogenic ${ }^{10} \mathrm{Be}$. However, they occur in three levels at similar elevations above the river bed as in the Buëch catchment. If we assume that the terraces of the Buëch and Drôme Rivers were abandoned simultaneously, long-term incision rates of the Drôme River can be estimated at about $0.7-0.9 \mathrm{~mm} \mathrm{y}^{-1}$. Terrace levels are parallel to the present-day river profile, suggesting that this rate is homogeneous along its course upstream of the mountain front (Brocard, 2002). 


\section{DIAGNOSTIC INDICES AND FIELD EVIDENCE FOR DETACHMENT- AND TRANSPORT-LIMITED RIVERS}

\section{Channel morphology}

The morphology and sediment pattern in active river channels can be used to define the river type (e.g., bedrock, alluvial, or mixed bedrock-alluvial; Howard, 1998) and the process of incision (e.g., Pazzaglia et al., 1998; Whipple et al., 2000). As river bed morphology is very sensitive to climatic and anthropogenic changes (e.g., Gautier, 1992; Snyder et al. 2003a), it must be used with care to assess the processes involved in river incision over the timescales required to shape river long profiles and valley flats (Personius, 1995; Wegman and Pazzaglia, 2002). However, our field observations along the Alpine rivers are consistent with the parameters describing the mode of long profile development exposed hereafter.

Upstream of the knickpoint discussed in the previous section, the Drac River flows over thick fluvio-glacial deposits within a wide and gentle valley, whereas it has incised up to 300-m deep gorges downstream. Where incising limestones, basalts and gneisses, the river exhibits a mixed bedrock-alluvial bed. All of these rocks are intensively folded and fractured. Abrasion features are restricted to massive limestone strata and gneisses. Elsewhere, incision appears to be dominated by plucking. Where incising marly levels, however, the river channel is braided and flows over a narrow strath; the bedrock is extensively covered with gravel in these reaches. In its lowermost reaches, the Drac River again flows over alluvial deposits from a large fan that developed at the confluence with the Romanche River after deglaciation

Rivers in the non-glaciated area are naturally braided and wander within wide valley flats. Their bedrock is usually entirely blanketed with a thin layer of channel sand-and-gravel deposits (Gautier, 1992). However, gravels have been intensively extracted from many river beds during the twentieth century, so that most of the bedload cover has been stripped off the active channels. The thickness of channel deposits is commonly a few meters; this is interpreted as the maximum thickness the river can remove during peak discharge stages (Mackin, 1937; Howard, 1998; Wegman and Pazzaglia, 2002). In many places, the rivers cross a thin but conspicuous series of Tithonian massive limestone, composed of submarine micritic breccia. Where rivers cross this unit, the valley floor is reduced to the active channel, at the bottom of narrow gorges. In some of these gorges, the rivers further exhibit knickpoints associated with outstanding abrasion features such as potholes. 
On the basis of these field observations, the rapidly incising Drac River can be regarded as a detachment-limited, plucking-dominated, mixed bedrock-alluvial river, with restricted transportlimited reaches, below its knickpoint. In contrast, the slowly-incising rivers of the non-glaciated catchments, as well as the upper Drac River, are alluvial or transport-limited mixed bedrockalluvial rivers. The use of other criteria hereafter will confirm this trend over longer timescales.

\section{Bedrock strength and slope variations in long profiles}

The long profiles of detachment-limited rivers are influenced by the (tensile) bedrock strength, which partly controls the parameter $K_{d}$ in the stream power law (Equation 1), whereas transport-limited long profiles are sensitive to bedload caliber (Snow and Slingerland, 1987; Gasparini et al., 1999; Sklar and Dietrich, 2001). We have investigated the effect of bedrock strength along the Drac River and along the non-glaciated rivers by constructing long profiles of the main rivers in the study area. Elevation and distance data were digitized from 1:25,000scale topographic maps with contour intervals of 10 meters. Along smaller streams, long profiles were extracted using Arcview GIS from a 50-meter resolution Digital Elevation Model (DEM) obtained from the Institut Géographique National (cf. http://www.ign.fr/). As grid nodes generally sample points on valley flanks rather than the valley floor, elevation data of long profiles are overestimated and very rough. This technique was only applied where changes in slope in the river profiles are larger, both in length and amplitude, than the highfrequency noise of the DEM data.

In Figure 4, the logarithm of gradient of the Drac River is plotted as a function of the logarithm of downstream distance. Equilibrium long profiles should plot as straight segments in such a diagram (Bishop and Goldrick, 2000). Lithological knickpoints are generated where equilibrium rivers cross zones of hard bedrock. Numerous knickpoints occur along the Drac River; they correlate with more resistant bedrock such as Mesozoic reef limestone and Paleozoic micaschist. The topographic resolution is not sufficient to construct lines along these reaches and evaluate the degree of equilibrium of these knickpoints. In contrast, a clearly unstable knickpoint is currently propagating toward the Drac headwaters into unconsolidated sediments deposited during the Last Glaciation (solid star in Fig. 4) separating the river long profile into two segments: a regularly graded upstream reach and a downstream reach with steep and highly variable gradients. Upstream of this knickpoint, bedrock is not exposed in the river bed and incision rates are roughly half those downstream (cf. previous sections). 
In the non-glaciated area, the sensitivity of the long profile to variations in bedrock strength appears to depend on stream power. Along small streams (Fig. 5), knickpoints occur where the streams cross massive limestones. In contrast, no knickpoints are observed along streams with discharges comparable to the Drac River, even where they cross hard lithologies, so that their long profiles become evenly concave (Fig. 6). Furthermore, the slopes of the large non-glaciated rivers are conspicuously similar and do not show any correlation with rock strength (Fig. 7).

In detail, the long profiles of the non-glaciated rivers locally exhibit very subdued knickzones (e.g. Ouvèze River, Fig. 6) or straight segments that correlate with outcrops of Tithonian limestone. The knickzones expand several kilometers upstream and downstream of the reaches where bedrock is composed of Tithonian limestone. Along the knickzones, the active channels are fed with limestone clasts from the surrounding cliffs. Based on visual observations, it appears that these are significantly coarser than the clasts delivered by other sources. Although other limestone units are resistant enough to generate knickpoints, their denser internal stratification precludes the delivery of clasts as large as those produced by the massive Tithonian limestone breccias.

It is worth noticing that the Tithonian limestones also deliver boulders that control the river gradients where their density is high (e.g., Maraize River, Fig. 5). In such locations along the smaller streams, the active channels are armored with boulders overlying the marly bedrock. The river gradients are considerably steeper than the gradient required to incise the marly levels. The boulders are too large to be transported during flood events and cannot be regarded as a part of the bedload. We would argue that the boulders are almost equivalent to Tithonian bedrock in these reaches.

As a conclusion, the Drac River and the small streams of the non-glaciated area behave as typical detachment-limited rivers in that they are sensitive to bedrock strength. The regular concavity of the non-glaciated river long-profiles, in contrast, cannot be explained by the detachment-limited stream power model. Their gradient is insensitive to bedrock changes but appears controlled by bedload caliber, a behavior typical of transport-limited rivers. Note that along the small streams, below the zone of debris-flow scouring, detachment-limited behavior is only observed in limestone-dominated reaches. Along reaches that cross marls and marly limestones, variations in bedrock erodibility do not induce changes in slope. Because the small streams of the non-glaciated area flow for most of their length over marls, detachmentlimited behaviour is limited to restricted reaches where the rivers cross the most resistant units 
(see further). Along the lower Drac River, in contrast, transport-limited behavior is restricted to short reaches crossing Aalenian marly limestones.

\section{Parallelism of alluvial and bedrock long profiles}

The Buëch River provides additional evidence for a bedload-controlled gradient along a bedrock river. Along its middle reaches, the river has incised its bedrock almost continuously since the Last Glaciation (Fig. 8). Its floodplain is underlain by a thin layer of sand-and-gravel deposits blanketing a wide strath. Upstream and downstream of these reaches, the river is reworking fluvio-glacial sediments that fill shallow glacial troughs carved during the last two glaciations. These loose sediments are easily detached and readily incorporated into the bedload, similar to sediments stored along alluvial rivers. The Buëch River thus behaves as an alluvial river along these formerly glaciated reaches. The long profiles of the bedrock and alluvial reaches are strikingly similar; no changes in slope are observed at the transitions between alluvial and bedrock reaches (Figs. 8 and 9). Moreover, the modern long profile in the bedrock reach is parallel to both the straths and the treads of the fill-terrace levels (Fig. 8). Therefore, the river gradient is clearly not set by bedrock strength.

\section{Slope-area scaling of long profiles}

Transport- and detachment-limited rivers may be distinguishable on the basis of the slope-area scaling behavior of their long profiles, although this may not in itself provide a diagnostic index (Whipple and Tucker, 2002). For detachment-limited rivers, the relationship between equilibrium slope and drainage area, for constant incision rate and erosional efficiency, can be written as (Whipple and Tucker, 2002):

$$
\begin{gathered}
\mathrm{S}_{d}=\left(\dot{E}_{d} / K_{d}\right)^{\left(1 / n_{d}\right)} \mathrm{A}^{-\theta_{d}} \\
\theta_{d}=m_{d} / n_{d}
\end{gathered}
$$

where $\mathrm{S}_{d}$ is the detachment-limited gradient, $\dot{E}_{d}$ the detachment-limited incision rate, and $\theta_{d}$ the intrinsic concavity. The pre-exponential constant $\left(\dot{E}_{d} / K_{d}\right)^{\left(1 / n_{d}\right)}$ is known as the steepness index. 
The relationship between equilibrium slope and drainage area can be written similarly for transport-limited rivers, assuming that incision rate is equal to the catchment erosion rate (Whipple and Tucker, 2002):

$$
\begin{gathered}
\mathrm{S}_{t}=\left(\beta \dot{E}_{t} / K_{t}\right)^{\left(1 / n_{t}\right)} \mathrm{A}^{-\theta t} \\
\theta_{t}=\left(m_{t}-1\right) / n_{t}
\end{gathered}
$$

where $\mathrm{S}_{t}$ is the transport-limited gradient, $\dot{E}_{t}$ the transport-limited incision rate, and $\beta$ the proportion of sediments produced by the watershed that is converted into river bedload. $\theta_{t}$ and $\left(\beta \dot{E}_{t} / K_{t}\right)^{\left(1 / n_{t}\right)}$ are the intrinsic concavity and steepness index of a transport-limited river, respectively.

We have compared the slope-area scaling for the Drac River to that of the slowly incising rivers of the non-glaciated area (Fig. 9; Table 2). Slopes were measured by digitizing the 1:25,000-scale topographic maps and drainage areas were extracted from the 50-m resolution DEM. Since lithologies may vary over very short distances along the river profiles, it is difficult to ascribe a specific slope value to any rock formation using the present data. Values of concavity and steepness indices as a function of lithological units are therefore not included in the following discussion.

The intrinsic concavities of the slowly-incising rivers are all remarkably similar and their gradients at any drainage area are clearly lower than those of the rapidly incising Drac River. The intrinsic concavity can be evaluated by linear regression through the profile data only if erosion rate $(\dot{E})$ and erosion or transport coefficient $\left(K_{d}\right.$ or $\left.K_{t}\right)$ are constant along the rivers. This is clearly not the case for the Drac River, where the retreating knickpoint zone at least is out of equilibrium and where bedrock erodibility is highly variable (Fig. 4). In its headwaters, large crystalline boulders are delivered to the Drac River bed by debris flows and rockfalls from surrounding hillslopes. Gradients in these reaches are, therefore, neither controlled by the bedrock nor by the bedload and are excluded from our analysis. The intrinsic concavity for the Drac River was, therefore, only evaluated upstream of the retreating knickpoint within the alluvial segment to which the postglacial base-level fall has not yet been communicated. This reach should behave similarly to the non-glaciated transport-limited rivers. The intrinsic concavity of the upstream alluvial reach of the Drac River is not significantly different from that of the Buëch and Drôme rivers, but the steepness index is. For the downstream bedrock 
reach in the Drac River, gradients are much steeper than for comparable drainage areas in the other rivers, but the large scatter in the data render values for the intrinsic concavity and steepness index meaningless. We expect such scatter to occur, because of the variable lithologies, the alternation of transport and detachment limited reaches, and the fact that we cannot unambiguously demonstrate equilibrium downstream of the knickpoint.

The intrinsic concavity is sensitive to the precipitation gradient within the watershed (e.g., Roe et al., 2002). Latitudinal and longitudinal gradients in mean annual precipitation are low troughout the study area, although they increase to the NW due to north-westerly damp oceanic winds (Fig. 10). The orographic gradients are more important. The mean and maximum elevations of the Drac River catchment are distinctly higher than those of the highest non-glaciated catchments (cf. Table 1). We therefore have to ensure that the higher gradients of the Drac River are not due to orographic effects. To test this hypothesis, we use precipitation records of the meteorological stations located in the study area, obtained from the Météo France database (http://www.meteo.fr/meteonet/temps/france/clim/cli.htm\#). The mean annual precipitation record is calculated over varying periods of time, depending on the timespan of operation of the stations (ca. 20 to 80 years). From the data, we determined the orographic gradient in the Vercors Massif, located at the core of the study area. This massif is particularly suitable for such an analysis because the stations are located in large and shallow valleys that do not affect the orographic gradient at the regional scale. In the higher-relief Pelvoux Massif, in contrast, data are more scattered because rain often falls on the downwind valleys and not on the mountains where it is generated. The observed altitudinal precipitation gradient in the Vercors Massif is close to linear (Fig. 10).

The orographic effect on concavity is taken into account by weighting the contributing area of each DEM cell by its elevation. Latitudinal precipitation gradients can be neglected at the scale of the study area when compared with the altitudinal gradient. The weighting applied to the DEM is:

$$
P_{i}=\left(0.65 Z_{i}+560\right) / 1032
$$

where $P_{i}$ is the weighting factor for grid cell $i$ and $Z_{i}$ is its altitude. The denominator represents the predicted precipitation at the average elevation $(726 \mathrm{~m})$ of the study area. Drainage areas were then extracted from the weighted grid using the ArcView flow 
accumulation function. Resulting slope-area relationships for the Drac and Drome rivers are shown in Fig. 11.

The figure shows that correcting for orographic effects, in fact, enhances the differences. As average precipitation is higher in the Drac catchment than in the non-glaciated catchments, the slope-area relationship becomes even steeper when using the weighted areas. The orographic weighting has negligible effect on the slowly incising rivers because they do not show large elevation differences. Differences in precipitation thus do not account for the observed differences in long-profile gradients.

Of course, present-day records must be considered with caution to explain fluvial forms that develop over $10^{4}-10^{5}$ y timescales. We lack proxy records of paleo-climate gradients during the Holocene and Upper Pleistocene. We expect, however, that the orographic gradient would increase during damper climate conditions (e.g., beginning of the Holocene), and decrease when climate is drier (e.g., during the end of the Last Glaciation). Moreover, mean annual precipitation cannot be used to assess the effect of large magnitude flood events, which potentially could play an important role in controlling fluvial morphology (e.g., Snyder et al., 2003b). A precise study of this effect from a statistical analysis of river gauging data (e.g., Tucker and Bras, 2000) would, however, require the same extrapolation when applied as a surrogate for paleoclimate.

It is commonly assumed that the intrinsic concavity of transport-limited systems is lower than that of the detachment-limited rivers, although there is in fact very little data to support this assumption (cf. Whipple and Tucker, 2002 and references therein). We have argued above that most of the downstream reach of the Drac River behaves as a detachment-limited system, whereas the Buëch and Drôme rivers are transport-limited. The slope-area relationships (Fig. 9) do not contradict the hypothesis that the intrinsic concavity of transport-limited systems is lower than that of detachment-limited systems, even though no statistically meaningful intrinsic concavity can be calculated for the downstream reach of the Drac River.

From a comparison of equations $3 \mathrm{a}$ and $4 \mathrm{a}$, it can be shown that higher incision rates only favor detachment-limited conditions if $n_{d}<n_{t}$ (Howard, 1980; Whipple and Tucker, 2002). The value of $n_{d}$ has been assessed to be around 2/3 (i.e., shear stress dependent) in the case of plucking-dominated incision and $5 / 3$ if abrasion prevails (Whipple et al., 2000). Field observations of the Drac River bedrock morphology suggest incision dominated by plucking (Section 2.1) which implies $n_{d} \approx 2 / 3$. Therefore, our data suggest the value of $n_{t}$ to be $>2 / 3$, 
and possibly close to 1, which is consistent with gravel bedload transport in rivers (cf. Whipple and Tucker, 2002 and references therein).

The slope-area plots of the slowly-incising rivers are clustered when compared with the great dispersal of the Drac River values. As uplift and incision rates can be regarded constant in the non glaciated area, the clustering suggests that rivers in this area are characterized by very similar $K_{t}$ values (Table 2). This indicates that either the caliber of the bedload evolves similarly along the transport-limited rivers, or that fluctuations in caliber generate only mild variations in gradient. We currently lack detailed bedload caliber data along these streams and are therefore not able to resolve this question in detail. The steeper long-profile gradient in the alluvial upper reach of the Drac River appears consistent with the larger incision rate and translates into an insignificantly different $K_{t}$ value for this reach, with respect to the slowlyincising rivers (Table 2).

\section{THE TRANSITION FROM DETACHMENT-LIMITED TO TRANSPORT-LIMITED CONDITIONS.}

It has been demonstrated theoretically (e.g. Howard, 1980; Whipple and Tucker, 2002) that a river can change from detachment- to transport-limited behavior along its course if the intrinsic concavities for transport-limited and detachment-limited incision are different. In the case of uniform lithology, uplift rate, sediment flux and river transport capacity, the river will shift from detachment- to transport-limited behavior downstream if $\theta_{d}>\theta_{t}$ (Fig. 12). The critical area where the transition occurs $\left(A_{c r}\right)$ can be found by stating $S_{d}=S_{t}$ in equations (3) and (4) and solving for area (Whipple and Tucker, 2002):

$$
A_{c r}=\left[K_{d}^{1 / n_{d}}\left(K_{t} / \beta\right)^{-1 / \mathrm{n}_{\mathrm{t}}}\right]^{1 /\left(\theta_{t}-\theta_{d}\right)} \dot{E}^{\left(1 / n_{t}-1 / n_{d}\right) /\left(\theta_{t}-\theta_{d}\right)}
$$

We have shown that the slowly-incising rivers switch from detachment-limited conditions (where they cross resistant rocks) upstream to transport-limited conditions downstream. Our study area is particularly suitable to test the influence of bedrock erodibility $\left(K_{d}\right)$ and incision rate $(\dot{E})$ on the critical drainage area $\left(A_{c r}\right)$. Other parameters are more difficult to test, but the influence of $K_{t}$ and $\beta$ could be evaluated in further studies of these rivers. 


\section{Influence of bedrock lithology}

Slope-area plots should show a kink at the critical drainage area if $\theta_{\mathrm{d}} \neq \theta_{\mathrm{t}}$. However, as lithology varies frequently along the streams we have studied here, the detachment-limited intrinsic concavity $\theta_{\mathrm{d}}$ is difficult to evaluate (cf. Fig. 9). Moreover, different rivers will not likely cross the same lithology at the point where the transition occurs and the transition will thus not be observed directly.

In order to constrain the critical area, we have, therefore, made an inventory of the occurrence or absence of knickpoints where rivers cross the most resistant lithological units. Drainage areas at these locations were extracted from the 50-m DEM. In total, some 200 knickpoints and 60 gorges without knickpoints were investigated (Fig. 13).

As predicted by the model, the critical drainage area scales with bedrock resistance: the most resistant units (Tithonian and "Urgonian" limestones) show knickpoints (and thus detachment-limited behavior) for the largest areas. In contrast, knickpoints disappear at smaller drainage areas for lesser resistant units (e.g., Hauterivian marly limestone). The upper threshold of knickpoint disappearance along the entire river system is set by the Tithonian limestone threshold and occurs between 30 and $45 \mathrm{~km}^{2}$.

The precise value of the critical area is, however, difficult to assess because at intermediate drainage areas some rivers demonstrate knickpoints when flowing over resistant units whereas others do not. Variations in the nature and caliber of sediment load, sediment flux, lithological strength and bedding strike and dip are the most probable factors responsible for this scatter. Preliminary field observations suggest that variations in bedrock bedding and fracturing, together with bedding dip, are the primary cause. The Gervanne River shows a dramatic illustration of this effect (Fig. 5): it does not show a clear knickpoint where it flows over steeply dipping Urgonian limestone, whereas it flows over the same but flat-lying unit in a spectacular knickpoint $3 \mathrm{~km}$ downstream. No evidence for possible groundwater sapping has been observed in the lower knickpoint. In addition to these effects, some knickpoints may be buried under ephemeral sediment accumulations or landslides. Finally, stochastic variations in sediment supply and river carrying capacity are expected to cause lateral shifts in the transition along a river (e.g., Whipple and Tucker, 2002). A part of the scatter could therefore also be explained by temporal displacements of the detachment- to transport-limited transition, triggered by high-frequency variations in the climatic forcing of the rivers' 
transport capacity. An unknown number of knickpoints and non-knickpoint reaches could thus be relict, non-equilibrium features.

We have argued above that it is reasonable to consider that uplift is homogeneous throughout the study area, but this cannot be firmly demonstrated. Thus, differences in uplift rate could also account for part of the dispersion. However, the data do not show any marked and logical spatial trend. If uplift gradients play a role in the dispersion, its effects are hidden by the addition of other processes.

In Fig. 12, we have placed the critical area for three types of lithology according to our analysis (Fig. 13), to show how bedrock resistance to erosion controls the area at which streams become transport-limited. The transition in the marly levels is difficult to observe because the critical area is small $\left(<10^{6} \mathrm{~m}^{2}\right)$ and possibly within the debris-flow realm (Stock and Dietrich, 2003). It also appears to be strongly controlled by the bedload characteristics. Marls such as the Oxfordian Black Shales only deliver small blocks of sandstone and vein calcite (typically $1 \mathrm{~cm}$ in length) as bedload to the streams. If the upstream watershed is only composed of such marls, badlands develop and streams are detachment-limited (e.g., Howard and Kerby, 1983). When the badlands propagate into the overlying marly limestones, bedload supply and caliber increase and the streams become transport-limited. Notwithstanding these uncertainties, the approximately 40 -fold increase in critical drainage area between the weakest and most resistant lithological units in our study area may be used to constrain variations in erodibility $\left(K_{d}\right)$ between these units from equation 6 if we suppose $n_{d}=2 / 3$ (as inferred previously). To do this requires an estimate for $\theta_{\mathrm{d}}$, however, which we will derive below.

\section{Influence of incision rate}

Using the incision rates inferred from cosmogenic dating (Brocard et al., 2003), the nonglaciated rivers and the Drac River can be used to put loose constraints on the evolution of the critical area $\left(A_{c r}\right)$ with incision rate, for some of the main encountered bedrock types (Fig. 14). Values of $A_{c r}$ for the slowly incising rivers are extracted from Fig. 13. As explained above, the critical area in marls is not easy to define but it is $<1 \mathrm{~km}^{2}$. Along the Drac River, only the value for marly limestones can be well constrained, as small transport-limited reaches occur on this lithology downstream. It appears to be nearly two orders of magnitude larger than the corresponding critical area for the slowly incising rivers. The probable location of the transition for marls in the Drac River is currently occupied by a glacial trough filled with 
sediments. The Drac River does not cross Tithonian limestone in its downstream reaches. However, it does cross lesser resistant lithologies that develop knickpoints. These less resistant units thus provide a lower limit for the critical area in Thitonian limestone. Altogether the data, although limited, are consistent with a power-law dependence of critical drainage area on incision rate, as predicted by equation (6). From a comparison of $A_{c r}$ for marly limestones we estimate the dependence to be close to cubic (Fig. 14), which is consistent with (6) for $n_{t}=1, n_{d}=2 / 3, \theta_{\mathrm{t}} \approx 0.4$ and $0.5<\theta_{\mathrm{d}}<0.6$.

\section{VALLEY-FLAT DEVELOPMENT: A DIAGNOSTIC FEATURE OF TRANSPORT LIMITED SYSTEMS}

\section{Description and behavior of valley flats in western Alpine rivers}

In our study area, we observe that valley flats wider than the river channel develop systematically as soon as the rivers become transport-limited (i.e., as soon as lithological knickpoints disappear). Along small slowly incising streams, and along large and intermediate rapidly incising rivers (i.e., the Drac river and its tributaries), valley flats only develop in marly levels. Within the same stratigraphic unit, the valley flat widens with increasing discharge. It also propagates into more resistant limestone units downstream (e.g. Fig. 15). In the field, we thus find the following suite of fluvial forms with increasing drainage area: (1) rivers showing a series of gorges with knickpoints separating reaches with well-developed valley flats; (2) rivers with a suite of valley flats of varying width, separated by narrow valleybottom segments with or without knickpoints; and finally (3) rivers without knickpoints and having a continuous valley flat of highly variable width. The development of a valley flat significantly larger than the channel is thus a diagnostic feature of the transport-limited reaches.

The valley flats are occupied by braided channels where these have not been contained by dikes. Meandering reaches are rare and restricted to smaller streams located at the western margin of the field area, near the alpine foreland (e.g., Roubion River, Fig. 2). The valley flats are generally composed of thin (2-5 m) sand-and-gravel deposits overlaying straths. Low fillterrace remnants can cover some parts of the straths, as observed along the Buëch and Drôme rivers, and are composed of sand-and-gravel channel-bed deposits with locally very thick 
covers of overbank deposits. ${ }^{14} \mathrm{C}$ dating suggests that these fill terraces were emplaced during distinct climatic events since the end of the Last Glaciation (Rosique, 1996).

Valley-flat widths range from a few tens of meters to several kilometers. The widest valley flat encountered is that of the Drôme River where it flows into the foreland (Fig. 15a); it is 3 $\mathrm{km}$ wide but the fluvial deposits covering it are no more than $12 \mathrm{~m}$ thick (Mandier, 1988). The main factors that control valley-flat width in our field area appear to be bedrock lithology, river discharge and incision rate.

To investigate these controls, we measured the valley-flat width at 3200 sites along 45 rivers from 1:25,000-scale topographic maps. Only the most common lithological units were investigated. We avoided transition zones from one bedrock type to another because of possible boundary effects, as well as valley flats obviously underlain by fill deposits of anomalous thickness and bedrock types that do not favor the preservation of clear valley-flat borders due to intense landsliding. Where proper segments could be found, valley-flat width was measured every $150 \mathrm{~m}$. Drainage area and downstream distance at each site were extracted from the 50 m-resolution DEM.

\section{Influence of bedrock lithology}

Along all the investigated streams, variations in valley-flat width are strongly controlled by bedrock lithology. Lithological forcing can observed directly in map view (e.g. for the Drôme River, Fig. 15a) or by plotting valley width and lithology along a single river (e.g., Céans River, Fig. 15b). Valley-flat widths vary suddenly where the rivers cross lithological boundaries. The local lithological units are mixes between limestones and clays; valley-flat width correlates positively with clay content in the bedrock. However, there is large scatter in the data: the variability of valley-flat width along a single bedrock segment is in many cases greater than the difference between two successive segments of different lithologies, or even than the difference between the mean widths of two different bedrock segments.

\section{Influence of drainage area}

The valley-flat width increases with discharge along single streams, as can be clearly observed along reaches crossing a single lithological unit (e.g., Fig 15b). However, it is necessary to correct for the lithological effect in order to better observe the influence of discharge. To 
achieve this, we have plotted the valley-flat width as a function of drainage area for different bedrock lithologies, compiling the width data for all rivers. We expect that valley-flat width $\left(W_{v f}\right)$ should have a power-law dependence on drainage area $(A)$ as has been observed elsewhere (Snyder et al., 2003a; Tomkin et al., 2003); we will provide arguments for and a derivation of this relationship in a later section:

$$
W_{v}=K_{v} A^{c_{v}}
$$

The data show, as expected, that valley-flat width scales with drainage area (Fig. 16; Table 3 ). The best-fit values of $c_{v}$ overlap the interval $0.3-0.4$ with $95 \%$ confidence whatever the lithology investigated, except for the Aptian marls (n6). The best-resolved values of $c_{v}$ (e.g., for $\mathrm{j} 2-\mathrm{j} 4, \mathrm{n} 1, \mathrm{n} 3$ ) all lie within the interval $0.3-0.4$. There appears to be a tendency for $c_{v}$ to decrease in the most resistant limestones (e.g., j5, j6, n4, n5) but this trend is not statistically significant.

Minimum and maximum values of the widening factor $K_{v}$ (taking $c_{v}=0.4$ ) are plotted as dotted lines for a few lithological units (Fig. 16). The valley-flat width increases significantly faster in more erodible lithologies such as the mid-Jurassic marls (j2-j4: $K_{v}=25-160 \mathrm{~m} \mathrm{~km}^{-0.8}$ ) than in the resistant mid-Cretaceous ("Urgonian") limestone (n5: $K_{v}=8-40 \mathrm{~m} \mathrm{~km}^{-0.8}$ ). Within the Hauterivian marly limestones (n3), valley-flat width increases at an intermediate rate $\left(K_{v}=\right.$ $10-100 \mathrm{~m} \mathrm{~km}^{-0.8}$ ).

The relatively high scatter of the limestone datasets stems from the higher relative error on width measurements in addition to various other factors. For example, the high scatter for the c3 limestones and n6 marls can be partly explained by non-negligible lateral facies variations in these units. In addition, some valley widths in c3 were measured in the hinge of a syncline located near the foreland that could be actively folding (cf. Fig. 2). The valley width at this locality is unexpectedly large. This can be either explained by the low dip angle of the strata or by very low uplift and incision rates in the synclinal hinge (see below).

\section{Influence of incision rate}

Valley flats are commonly thought to narrow with increasing incision rate. From field observations, the valley flat was found either to follow such a trend along a single river (e.g. Harbor, 1998) or to not correlate with uplift rate when comparing different rivers (Snyder et 
al., 2003a). We can test the potential influence of incision rate by comparing the valley-flat width in the most downstream section of the rapidly incising Drac River, where it exhibits transport-limited characteristics, with that of the slowly incising rivers. As the Drac River cuts through Lower Jurassic series in its downstream reaches, whereas the slowly incising rivers incise Upper Jurassic and Cretaceous rocks, we cannot directly compare data for the same unit. We therefore compare the bedrock underlying the Drac valley-flat (Aalenian marly limestone) with the most similar unit, in terms of lithological composition and bedding thickness, of the non-glaciated area (Hauterivian marly limestone; Fig.16-1). For similar drainage areas, the valley flat of the Drac River is an order of magnitude narrower than the valley flats of the slowly incising rivers. This observation clearly supports the common assumption of a narrowing of valley flats with increasing incision rate, and suggests the relationship between valley-flat width and incision rate to be inversely linear.

\section{A model for valley-flat development: the erosion frequency}

From the field data, it appears that the valley-flat width along transport-limited rivers is controlled by the same factors that control the gradient of detachment-limited rivers. In contrast, the gradient of the transport-limited rivers is set by the bedload caliber. By definition, incision rate and bedrock strength do not modulate the transport-limited stream gradient directly; they only act indirectly on the profile shape by affecting the flux and caliber of the slope debris delivered to the streams. The fact that valley flats develop as soon as detachmentlimited conditions disappear is a strong indication that the valley flat accommodates most of the variations in bedrock strength and incision rate along transport-limited rivers.

\section{Factors controlling the valley-flat width}

We propose that the valley-flat width reflects the frequency of strath erosion. Along transportlimited reaches, erosion occurs during stages that are high enough to rework the alluvial layer down to the strath. The braided and meandering streams wander over the strath from one side of the valley flat to another. Over large periods of time, the frequency of erosion of any point of the strath $(F)$ should be independent of the frequency of channel switching and be set primarily by the widths of the active channel $\left(W_{c}\right)$ and valley flat $\left(W_{v}\right)$ (e.g., Tomkin et al., 2003): 


$$
F=W_{c} / W_{v}
$$

The erosion frequency will be controlled by ratio of the actual (transport-limited) incision rate and the potential (detachment-limited) incision rate:

$$
F=\dot{E}_{t} / \dot{E}_{d}
$$

so that:

$$
W_{v}=\left(\dot{E}_{d} / \dot{E}_{t}\right) W_{c}
$$

By combining (10) with equations (1) and (2c) for detachment- and transport-limited incision, respectively:

$$
\begin{aligned}
W_{v} & =\left(\frac{K_{d} A^{m_{d}} S^{n_{d}}}{K_{t} A^{\left(m_{t}-1\right)} S^{n_{t}}}\right) W_{c} \\
& =\left(\frac{K_{d}}{K_{t}}\right) A^{\left(m_{d}+1-m_{t}\right)} S^{\left(n_{d}-n_{t}\right)} W_{c}
\end{aligned}
$$

\section{Relationship between valley-flat width and drainage area}

We did not compare $W_{v}$ and $W_{c}$ directly along the rivers, because $W_{c}$ varies at very short timescales. Instead, we use a relationship that links channel width $\left(W_{c}\right)$ and drainage area $(A)$, in the scope of establishing a time-averaged channel width. This also allows us to investigate the direct relationship between valley-flat width and drainage area described previously.

The active channels of transport-limited streams flow over a bed composed of channel sand-and-gravel. They should thus behave like alluvial rivers (Howard, 1998; Whipple and Tucker, 2002) and their bankfull channel width $\left(W_{c}\right)$ should depend on the river discharge $(Q)$ (e.g., Leopold and Maddock, 1953):

$$
W_{c}=K_{a} Q^{a}
$$


where $K_{a}$ is a dimensional coefficient and $a$ a positive exponent; $a$ has frequently been shown to be close to 0.5 (e.g., Leopold and Maddock, 1953). The drainage area $(A)$ is generally used as a proxy for $(Q)$ through a power-law relationship for basin hydrology:

$$
Q=K_{q} A^{b}
$$

where $K_{q}$ is a dimensional coefficient and $b$ a positive exponent; $b$ generally lies between 0.7 and 1 (e.g. Talling and Sowter, 1998; Stock and Montgomery, 1999; Snyder et al, 2003a). The relation between bankfull channel width and drainage area leads to the functional form:

$$
W_{c}=K_{c} A^{c}
$$

with $K_{c}=K_{a} K_{q}$ and $c=a b$. Combining (12) and (15) yields:

$$
\begin{aligned}
W_{v} & =\left(\frac{K_{d} A^{m_{d}} S^{n_{d}}}{K_{t} A^{\left(m_{t}-1\right)} S^{n_{t}}}\right) K_{c} A^{c} \\
& =\left(\frac{K_{d} K_{c}}{K_{t}}\right) A^{\left(c+m_{d}+1-m_{t}\right)} S^{\left(n_{d}-n_{t}\right)}
\end{aligned}
$$

We can now use the power-law relationship between slope and area for transport-limited rivers (Eq. $4 \mathrm{a})$ to retrieve a relationship between valley width and drainage area as in (7):

$$
\begin{aligned}
W_{v} & =\left(\frac{K_{d} K_{c}}{K_{t}}\right) A^{\left(c+m_{d}+1-m_{t}\right)}\left[\left(\frac{\beta \dot{E}}{K_{t}}\right)^{\frac{1}{n_{t}}} A^{\frac{\left(1-m_{t}\right)}{n_{t}}}\right]^{\left(n_{d}-n_{t}\right)} \\
& =\left(\frac{K_{d} K_{c}}{K_{t}}\right)\left(\frac{\beta \dot{E}}{K_{t}}\right)^{\frac{\left(n_{d}-n_{t}\right)}{n_{t}}} A^{\left(c+m_{d}+\frac{n_{d}\left(1-m_{t}\right)}{n_{t}}\right)}
\end{aligned}
$$

Whether the relationship between channel and valley width is linear thus depends on the values of $m_{d}, m_{t}, n_{d}$ and $n_{t}$. For the values inferred in the previous section $\left(n_{t}=1 ; n_{d} \approx 2 / 3 ;\left(m_{t}\right.\right.$ $\left.-1) / n_{t} \approx 0.4 ; 0.5 \leq m_{d} / n_{d} \leq 0.6\right)$ the scaling between $W_{v}$ and $W_{c}$ should be close to linear. Recent studies have come up with power-law exponents for valley widths that were either 
similar to those for channel widths (Snyder et al., 2003a) or significantly larger than these (Tomkin et al., 2003).

We have constrained values of $c_{v}$ (Eq.7) for different lithological units and showed that best-fit values lie between 0.3-0.4. These values are similar to or lower than values for $c$ obtained by measuring downstream variations in channel width from 1:25,000-scale topographic maps. For the present-day Drôme River, we determined $c=0.57\left(r^{2}=0.66\right)$. The present-day data are not representative of the long-term character of the river, however, because river width has been reduced artificially in many places during the $20^{\text {th }}$ century (Gautier, 1992; Landon, 1999). Scarce $18^{\text {th }}$ century data for the Buëch River in its "natural" state (Gautier, 1992) suggest that $c \approx 0.35$. We therefore consider a value for $c$ of 0.57 as a maximum estimate. At present, we cannot unambiguously decide whether the channel-width and valley-width exponents are the same in our study area. This would require making an inventory of non-disturbed channel widths, and these are difficult to find. Morevover, one could argue that the bedrock strath is only stripped off its sediment cover during peak discharges. Because such floods are triggered by precipitation events on restricted areas, the exponent $b$ that relates discharge to drainage area may decrease with discharge, and the value that is appropriate for scaling bankfull channel width and area may not be the relevant scaling factor for valley width.

According to the model, bedrock erodibility acts on the valley-flat width through the parameter $K_{d}$ (Eq. 17). As expected, $K_{v}$ values are lower for resistant rocks and larger for softer rocks (Fig. 16; Table 3). However, the scatter in the data is too large to propose characteristic values for each lithological unit. The dispersion in the data, like that for the critical area of the detachment- to transport-limited transition, can be ascribed to a variety of factors. In order of decreasing supposed importance we can quote: the volume and caliber of the sediment load, variations in the composition of lithological units at the regional scale, and bedding strike and dip with respect to valley orientation.

\section{Substituting spatial changes in discharge by temporal changes in discharge}

Temporal fluctuations in river regime and dynamics are responsible for the formation of paired strath terraces, as observed along the Drôme, Buëch and Gervanne rivers, by successive valley-flat enlargement and reduction. These terraces attest to the effects of river carrying capacity, sediment load and caliber in modulating valley widths. Where paired terraces are 
preserved, it is possible to estimate the former valley-flat width. The most suitable level for such an analysis is the T2 level of the Drôme River, supposed to be 60-75 ky old. We measured the width of the palao-valley flat represented by this level where possible and extracted drainage areas at these sites from the 50-m resolution DEM, assuming that drainage areas have not evolved through time. This assumption is reasonable, considering that no significant stream capture occurred in the catchment since the abandonment of the terrace level.

As for downstream increases in valley-flat width, our model predicts that bedrock strength should modulate the rate at which the valley flat enlarges during cold periods. The ratio of the paleo-valley width over the active valley width should be constant within each bedrock unit. Our analysis suggests that the valley flat was 1.2 to 2 times wider than present during the Last Glaciation (Fig. 17). There appears to be some correlation between widening factor and bedrock erodibility, but the scatter of the data does not allow investigating the bedrock control on widening quantitatively. Moreover, widening on the Oxfordian marly levels (j4) has been restricted because the terrace edges encountered Kimmeridgian marly limestones (j5) on both sides of the valley. A similar phenomenon occurred when the paleo-valley flat widened in the Hauterivian marly limestones (n3) until it encountered Barremian limestone (n4). Our estimates of widening factors in these lithologies are therefore minimum estimates.

As is the case for the detachment- to transport-limited transition zones, climate variability during the Pleistocene could partly explain the scatter in valley-flat widening factors, because it should act on river regime and overall discharge. It is also possible that the rock strength itself depends on climate trough the probable development of thick permafrosts. The variability of the valley-flat width in a given rock type may, finally, also be explained at some places because the terraces have not evolved over a time long enough to reach the potential valley-flat width. Valley-flat widening in response to changes in discharge and sediment flux is a process that may take many thousands of years (Hancock and Anderson, 2002). This effect may be especially important along the marly levels where the erosion frequency is low, because the valley flat is very wide. Correcting for it requires an assessment of valley-flat maturity. Mature valley flats should exhibit poorly curved borders with less intense and frequent variations in strike than their active channels. Immature reaches are characterized by portions of valley flanks with irregularities that are more similar to that of the active channels. 


\section{DISCUSSION}

Our field observations in western Alpine rivers lead us to propose a model for fluvial response to variations in bedrock strength, bedload supply and tectonically or climatically driven incision rates that combines detachment-limited and transport-limited behavior.

We have shown that slowly-incising "equilibrium" streams in our study area are detachment-limited in their upstream reaches and show a transition to transport-limited behavior downstream. The Drac River, which incises an order of magnitude more rapidly because it has been pushed out of equilibrium during glaciations, shows an inverse pattern: it is transport-limited upstream of a retreating knickpoint, which represents the present-day limit to where postglacial base-level drop has been communicated up the river, and detachmentlimited downstream. Observations and characteristics that permit to distinguish between transport-limited and detachment-limited behavior include the channel morphology, river gradients, the occurrence or absence of lithological knikpoints and the development of a valley flat. The latter two characteristics are the most diagnostic: within detachment-limited reaches, rivers react to variations in bedrock strength by adjusting their gradient, whereas in transport-limited reaches, they react by adjusting their valley-flat width.

By mapping out the occurrence of knickpoints we have constrained the critical area for the transition from detachment-limited to transport-limited behavior, and have quantified the influence of rock strength and incision rates on the location of this transition. These data allow us to make estimates of model parameter values that we will outline below. An important aspect of our model is the behavior of transport-limited streams: their gradients are set by bedload supply and caliber, and are not directly influenced by bedrock strength or incision rate. There is, however, an indirect control of these parameters on transport-limited gradients through the dependence of the flux and caliber of bedload that is delivered to the streams on erosion rate and rock type. We have shown that transport-limited rivers respond to variations in rock strength and incision rate by adjusting their valley-flat widths in a predictable and quantifiable manner.

Many of our observations of the interrelationships between bedrock strength, incision rate, discharge, river gradients and valley widths are corroborated by similar observations in comparable settings, e.g., for streams in Northern California (Snyder et al., 2003a) and Oregon (Personius, 1995); the Clearwater River in the Olympic Mountains (Pazzaglia and Brandon, 2001; Wegman and Pazzaglia, 2002), the Sevier River in Utah (Harbor, 1998), or 
rivers crossing the Lesser Himalayas of Nepal (Lavé and Avouac, 2001; Attal and Lavé, this volume). Our dataset contributes to the global set of observations with the advantage that it was collected in a restricted area with constant tectonic uplift rates but strongly varying incision rates, for rivers that are both in and out of equilibrium, and locally strongly variable but regionally homogeneous bedrock.

The conceptual model we distil from our observations has important implications for river incision models, the coupling between uplift / incision rates and river profiles in equilibrium settings and the stability of drainage networks. We will concisely explore these consequences below.

\section{Ability of models to reproduce the observed fluvial morphology}

Models used to study fluvial incision at the orogen scale are often based on a simple detachment-limited description (e.g., Whipple et al., 1999; Willett et al., 2001). Our study of the Western Alps shows that many rivers do not behave as detachment-limited bedrock rivers, and would therefore be inappropriately modeled by such a description. Our data indicate that the drainage net comprises a mixture of detachment- and transport-limited reaches, the pattern of which is controlled by a transition that depends on drainage area, lithology and incision rate. Such a pattern has recently been proposed from theoretical considerations (Whipple and Tucker, 2002). Our data are consistent with the Whipple and Tucker (2002) model of combined detachment-limited and transport-limited behavior, and are accurate enough to evaluate some parameters of the model.

The steady-state solution to the transport-limited model that we use in equation (4) assumes that the river incision rate is equal to the catchment-wide erosion rate (Whipple and Tucker, 2002). In the non-glaciated catchments, this assumption appears reasonable, since sediment storage is reduced to thin layers of colluvium on the slopes. Moreover, short-term catchment denudation rates, calculated from sediment mass balances integrated over a few decades (Alary, 1998) to centuries (e.g., Brocard, 2004), are not significantly different from long-term river incision rates. Finally, in many places the valley flanks preserve large pediments that bear witness to former stages of valley development. No changes in slope steepness or flank amplitude can be noticed between pediment surfaces and active valley flanks, suggesting that the relief is in steady state. 
From a comparison of equations (3) and (4), it appears that the downstream transition from detachment- to transport-limited conditions requires $m_{d} / n_{d}$ to be larger than $\left(m_{t}-1\right) / n_{t}$, whereas the tendency toward detachment-limited conditions at higher incision rates require that $n_{d}$ be smaller than $n_{t}$. Since we suspect plucking to be the dominant incision process in the detachment-limited reaches, their incision should be controlled by shear stress and $n_{d}$ should be around 2/3 (Whipple et al., 2000). As argued by Whipple and Tucker (2002), a value for $n_{t}=1$ appears an appropriate estimate for gravel transport. From a comparison of the critical drainage area $\left(A_{c r}\right)$ for different incision rates for a single lithology, we estimate the exponent in equation (6) that describes this scaling to be close to 3 , which is consistent with $n_{t}$ $=1, n_{d}=2 / 3,\left(m_{t}-1\right) / n_{t} \approx 0.4$ and $0.5<m_{d} / n_{d}<0.6$, so that $m_{t}$ should be around 1.4 and $m_{d}$ comprised between 0.3 and 0.4 . Because $m_{t}$ embeds the exponent on the channel width-area relationship $c$, which is close to 0.6 where we measured it (but note the problems with measuring present-day channel widths in our study area outlined in Section 4.5), this requires the sediment flux in the transport-limited rivers to scale approximately with the square of drainage area (i.e., $m_{t}{ }^{\prime} \approx 2$ in equation $2 \mathrm{a}$ ), consistent with the derivation of a sediment transport equation from the Einstein-Brown equation (Willgoose et al., 1991). Finally, we can estimate appropriate $K_{d}$ values by solving (6) for $K_{d}$ :

$$
K_{d}=\left[A_{c r}^{\left(\theta_{t}-\theta_{d}\right)} \dot{E}^{\left(1 / n_{d}-1 / n_{t}\right)}\left(K_{t} / \beta\right)^{1 / \mathrm{n}_{\mathrm{t}}}\right]^{n_{d}}
$$

Taking $A_{c r}=10^{6}$ and $4 \times 10^{7} \mathrm{~m}^{2}$ for marls and limestones, respectively (cf. Fig. 13), $\dot{E}=$ $0.8 \mathrm{~mm} \mathrm{y}^{-1}, K_{t}=4.5 \times 10^{-5} \mathrm{~m} \mathrm{y}^{-1}$ (cf. Table 2), $\beta=1$ and the other parameters as above, we find that $K_{d}$ should lie between $1.8-4.7 \times 10^{-5} \mathrm{~m}^{0.4} \mathrm{y}^{-1}$ for marls and between $1.1-3.7 \times 10^{-5} \mathrm{~m}^{0.4} \mathrm{y}^{-1}$ for limestone. A roughly twofold variation in erosional resistance between the "softest" and "hardest" lithologies in our study area is consistent with our estimates of the widening factors for valley-flats in these lithologies (cf. Fig. 16, Table 3), which are linearly dependent on bedrock erodibility in our model. These $K_{d}$ values could be compared with experimental measures of erodibility or tensile rock strength (e.g., Sklar and Dietrich, 2001; Lavé and Avouac, this volume) in order to test whether we have completely separated lithological effects from other controls on incision in our model.

The above constraints on model parameters, specifically those for detachment-limited incision, are similar to earlier estimates by Stock and Montgomery (1999), Snyder et al. 
(2000) and van der Beek and Bishop (2003). The latter study, which concentrated on the Upper Lachlan River, a low-relief, low-incision rate catchment on crystalline basement rocks in SE Australia, found that a detachment-limited incision model provided the best fits of five different model formulations tested, for $m_{d}=0.3-0.4, n_{d}=0.7$ and $K_{d}=7 \times 10^{-7} \mathrm{~m}^{0.4} \mathrm{y}^{-1}$. Although the concordance in exponent values between these independent studies is promising, two discrepancies require an explanation. Firstly, why do detachment-limited conditions appear much more widespread in the Lachlan catchment (as shown by the persistence of lithological knickpoints up to drainage areas of at least $1000 \mathrm{~km}^{2}$ and the relatively good performance of a simple detachment-limited stream power model in predicting incision) whereas incision rates in the Lachlan catchment are at least two orders of magnitude lower than in the Alpine Rivers? Secondly, the two-orders-of-magnitude difference in estimated $K_{d}$ values between these two studies requires an explanation, even though these values are both within the range of values estimated in different settings by Stock and Montgomery (1999). The difference in lithology underlying both study areas (calcareous sediments in the western Alps; granites and metasediments in the Lachlan catchment) will undoubtedly have an effect on $K_{d}$; the direction of change matches our a-priori expectations (i.e., the Lachlan catchment is underlain by harder bedrock than the western Alpine rivers). We are not able to quantify the lithological effect at this stage; this would require extending our Alpine study into the crystalline massifs where the glacial disruption of river profiles is, however, ubiquitous. An alternative explanation for large variations in $K_{d}$ values between areas with different incision rates could be the presence of erosion thresholds and a stochastic distribution of flood events, as proposed by Snyder et al. (2003b). In any case, the significantly lower $K_{d}$ values for the Lachlan River compared to the western Alpine rivers would promote detachment-limited behavior. Moreover, there is a significant difference in bedload caliber in that the Lachlan River only carries sand. This much finer bedload (in comparison with the western Alpine rivers) will require much lower transport-limited slopes and therefore promote detachmentlimited conditions.

Even though our observations are consistent with the model proposed by Whipple and Tucker (2002), they do not exclude other model formulations. In particular, our data appear equally consistent with either "Undercapacity" (Beaumont et al., 1992) or "Tools" (Sklar and Dietrich, 1998) models, which take the effect of sediment flux on bedrock incision more fully into account. As shown by van der Beek and Bishop (2003), their end-member cases, if sediment flux is close to or far from carrying capacity, are equivalent to the transport-limited 
and detachment-limited stream power models, respectively. In most cases, both these models will also predict downstream transitions from "detachment-limited-like" to "transport-limitedlike" behavior, but they predict gentler transitions from one to the other, without a clearly defined critical drainage area (van der Beek and Bishop, 2003). Although these models are intuitively more realistic than the simple stream power approach, they are also more difficult to test because they require constraining variables such as sediment fluxes and channel widths. Along most of the investigated rivers, the width of the anastomosing channel belt is very sensitive to factors such as fluctuating anthropogenic pressure (deforestation) and short-term climatic changes (e.g., the Little Ice Age). Moreover, many rivers have been embanked since the Middle Ages (e.g., Bouchayer, 1925; Gautier, 1992). The evaluation of long-term channel widths is thus difficult. Therefore, the transport- versus detachment-limited incision model is, given the present resolution of our data, the simplest model that is both testable and consistent with our data.

However, none of these models currently include the development of a valley flat, where river incision is evenly distributed over a strath that is considerably wider that the bankfull channel. To our knowledge, the only model in which strath formation was explicitly studied is that of Hancock and Anderson (2002). In that model, however, strath widening rates are simply assumed to be constant and independent of rock type or drainage area, whereas our data show that these parameters strongly influence widening rates. From our study, valley flats appear as important features, as they accommodate lithological, climatic and tectonic forcings, and thus potentially provide crucial information about spatio-temporal variations in uplift rate or climate. Moreover, the geomorphologic imprint of valley flats is not negligible as they may occupy significant portions of the topography.

\section{Coupling and decoupling between uplift / incision rates and fluvial profile form}

Following the conceptual work of Whipple and Tucker (1999), several authors have attempted to use fluvial profile forms to directly infer incision / uplift rates in "equilibrium" rivers (e.g., Kirby and Whipple, 2001; Finlayson et al., 2002). These studies use the relationship between river gradient and drainage area predicted by the steady-state formulation of the detachmentlimited stream power law (i.e., equation (3)). There is, however, an obvious problem in the basic assumptions of this approach if rivers become transport-limited. For decreasing uplift and incision rates, there will be a stage where transport-limited slopes are higher than 
detachment-limited slopes, and river gradients do not decrease further. Instead, valley widening will take over in order to expend the excess incision capacity. Therefore, river gradients may be much less sensitive recorders of rock uplift rates, and rivers may have a much greater degree of freedom in adapting to variable uplift rates, than previously assumed. An indication of this effect can be found in the data presented by Snyder et al. (2000), which show a much weaker correlation between river gradients and uplift/incision rates than predicted by the detachment-limited stream power model (except if $n_{d}>>1$, which is theoretically implausible). Similarly, Tomkin et al. (2003) found that no single model fits incision data for the Clearwater River in the Olympic Mountains, which has to adapt to orderof-magnitude variations in long-term uplift rates along its length. Snyder et al. (2003a,b) suggest that a threshold for incision combined with a stochastic distribution of floods may play a role to explain this discrepancy, but their model is not unique. While we have not tested the potential contribution of incision thresholds and discharge stochasticity in our field area, and the observed large variations in $K_{d}$ values between the western Alpine rivers and the Lachlan River suggest that this effect may play a role (cf. above), our observations clearly suggest that sediment flux and caliber exert an important non-tectonic constraint on river profiles.

\section{Stability of detachment- and transport-limited drainage networks}

The question of drainage stability and the notion of stream piracy have been important issues in large-scale fluvial geomorphology. Bishop (1995) provides a review of the processes involved and outlines the problems associated with both the notion of stream capture and that of drainage stability through the erosion of significant amounts of crustal section. In particular, stream capture requires the head of one stream to retreat across a drainage divide and into the catchment of another stream. Our model suggests under what circumstances this may be achieved and under what circumstances, in contrast, the drainage net remains stable through the erosion of different stratigraphic units.

The stream network of the non-glaciated part of our study area is composed of detachment-limited reaches, the gradients of which vary with bedrock strength; and of transport-limited reaches, the gradients of which are insensitive to lithological variation. We have shown that the Tithonian limestones trigger the formation of knickpoints on the course of streams that drain areas up to $40 \mathrm{~km}^{2}$ (Fig. 13). At equilibrium, both detachment-limited 
and transport-limited reaches incise at the same rate. However, the bedrock is strongly folded and composed of stratigraphic units with highly contrasting strengths. As the structures are incised, the folded and tilted layers responsible for the formation of knickpoints migrate in plan view with respect to the stream network. The response of the detachment-limited and transport-limited reaches to the displacement of a band of resistant bedrock is different, and is illustrated here by two field examples from the Drôme catchment (Fig. 18).

Several small tributaries of the Drôme River that flowed over marly levels up to a few tens of thousands of years ago have recently encountered Tithonian limestone on their course (Fig. 18a,b). As these tributaries have drainage areas smaller than the critical area in Tithonian limestone, they have developed pronounced knickpoints where crossing this unit. The knickpoints grow in amplitude as long as the tributaries' incision does not keep pace with that of the main stem. As the knickpoint acts as the baselevel for the upstream reaches, incision rate is reduced upstream during knickpoint growth and the streams are uplifted with respect to the surrounding streams. This makes them potential targets for capture by headward retreat of the surrounding stream heads through easily erodible lithologies According to the valley-flat model, the phenomenon should be enhanced by an increase of the valley-flat width upstream of the knickpoint as incision rate is temporarily lowered. In the example shown in Fig. 18a, a suite of captures is about to occur. At the final stage, all tributaries will flow parallel to the structural strike (Fig. 18c). Once the captures have occurred, the crests of Tithonian limestone will exhibit windgaps. Numerous windgaps are preserved throughout the study area and record an intense activity of drainage reorganization (Fig.13). They are readily distinguishable from common passes in that they appear as notches across the mountain crests and lithological units. They preserve very low axial slopes that can only be achieved by stream erosion. Other ongoing capture sites can detected in many localities (Fig. 13), and a dramatic capture has occurred in historical times (upper Maraize River, Goguel, 1954).

The transport-limited streams, in contrast, are insensitive to the geological structure. This lack of adaptation is well illustrated by the confluence of the Drôme and Sûre rivers, where the network is clearly superimposed on the structures (Fig. 18d). A Tithonian limestone layer has recently been excavated by the lower course of the Sûre River. The formation of a knickpoint would soon have triggered the capture of the Sûre River upstream of the limestone layer to the neighbouring Drôme River, but the Sûre is a transport-limited river where it reaches the Tithonian limestone and no knickpoint has developed. The hairpin loop of the 
Sûre River at its confluence with the Drôme is thus a stable feature that will be maintained throughout its incision history.

The drainage network thus presents a threshold for stability that is set by the transition from detachment- to-transport-limited behavior of the most resistant bedrock type. Smaller streams are less stable and continuously adapt to the bedrock structure, while larger streams are fully superimposed. This may explain why examples of small-scale stream capture are ubiquitous, but no unequivocal examples of large-scale river piracy are known (Bishop, 1995).

\section{CONCLUSIONS}

The drainage network of the non-glaciated western Alps can be regarded as a mixture of transport-limited and detachment-limited reaches. Evidence for both transport-limited and detachment-limited incision can be found in the field, and other diagnostic features such as the intrinsic concavity are in accordance with theoretical predictions for these two models. As expected, the transition from detachment- to transport-limited behavior occurs with increasing discharge. The transition shifts upstream with increasing bedrock erodibility and decreasing incision rate. The exact form of the transition, whether it is sharp or progressive, cannot be evaluated from our field data because the same bedrock lithology cannot be followed over sufficient lengths along a single stream. A valley flat develops systematically in association with transport-limited segments. The factors that control the detachment-limited river gradient (i.e., bedrock strength and incision rate) are transferred to the valley-flat width, while the transport-limited river gradient is far less sensitive to these factors. Thus, the valley-flat width increases with increasing bedrock erodibility, increasing discharge and decreasing incision rate. A model for valley-flat development, based on the frequency of strath erosion, has been proposed. It reasonably accounts for most of the observed trends in valley-flat widths. However, the valley-flat width data exhibit a high scatter that could reflect the effects of bedrock heterogeneity and variability in bedload caliber throughout the study area. The map pattern of the dispersion does not show any trend that could correlate with possible previously unrecognized gradients in rock uplift; further calibrations are needed to extract any possible tectonic forcing. They should take into account the orientation of bedrock fabric relative to the river strike, the intrinsic variability of the lithological units within the studied area and an 
assessment of the variability of the bedload characteristics. Such investigations are needed to make the analysis of fluvial forms an efficient tool for the detection of neotectonic activity in moderately active orogens.

\section{Acknowledgements}

Funding for this project was provided by the Institut National des Sciences de l'Univers (INSU-CNRS) through Programme National de Recherche Sols et Erosion project 99PNSE07. Many of the statistical analyses have been performed by Florence Revol. We thank Nicole Gasparini and Jonathan Tomkin for their thorough reviews of the manuscript, and Mark Brandon for editorial handling. 


\section{REFERENCES}

Alary, C., 1998, Mécanismes et bilans de l'érosion dans un bassin versant méditerranéen aménagé: le cas de la Durance (S-E France) [Ph.D. Thesis]: Université Aix-Marseille III, 255 p.

Attal, M., and Lavé, J., 2004, Changes of bedload characteristics along the Marsyandi River (central Nepal): Implications for understanding hillslope sediment supply, sediment load evolution along fluvial networks and denudation in active orogenic belts, in Willett, S.D., Hovius, N., Brandon, M.T., and Fisher, D., eds., Tectonics, Climate and Landscape Evolution: Geological Society of America Special Publication (this volume).

Beaumont, C, Fullsack P., and Hamilton J., 1992, Erosional control of active compressional orogens, in McClay, K.R., ed., Thrust Tectonics: Chapman Hall, London, p.1-18.

Benda, L., and Dunne, T., 1997, Stochastic forcing of sediment routing and storage in channel networks: Water Resources Research, v. 33, p. 2865-2880.

Bernet, M., Zattin, M., Garver, J.I., Brandon, M.T., and Vance, J.A., 2001. Steady state exhumation of the European Alps: Geology, v. 29, p. 35-38.

Bigot-Cormier, F., Poupeau, G., and Sosson, M., 2000, Dénudations différentielles du massif cristalin externe alpin de l'Argentera (Sud-Est de la France) révélées par thermochronologie traces de fission (apatites, zircons): Compte Rendu de l'Academie des Sciences de Paris, Sciences de la Terre et des Planètes, v. 330, p. 363-370.

Bishop, P., 1995, Drainage rearrangement by river capture, beheading and diversion: Progress in Physical Geography, v. 19, p. 449-473.

Bishop, P., and Goldrick, G., 2000, Geomorphological evolution of the East Australian continental margin, in Summerfield M.A. ed., Geomorphology and Global Tectonics: John Wiley \& Sons Ltd, Chichester, p. 225-254. 
Bouchayer, A., 1925, Le Drac dans la plaine de Grenoble de 1280 à 1651 : Revue de Géographie Alpine, v. 13, p. 115-173.

Brocard, G., 2002, Origine, variabilité spatio-temporelle et signature morphologique de l'incision fluviatile dans les Alpes du Dauphiné (SE France) [Ph.D. Thesis]: Université Grenoble 1. Géologie Alpine, Mémoire Hors Serie, no. 37, 165 p.

Brocard, G., 2004, Le grand lac du Claps de Luc-en-Diois (Drôme): évaluation, à la lumière d'une analyse morphologique, du volume d'un lac comblé: Bulletin de la Société Géologique de France, v. 175, p. 303-312.

Brocard, G.Y., van der Beek, P. A., Bourlès, D.L., Siame, L.L., and Mugnier, J.-L., 2003, Long-term fluvial incision rates and postglacial river relaxation time in the French Western Alps from ${ }^{10} \mathrm{Be}$ dating of alluvial terraces with assessment of inheritance, soil development and wind ablation effects: Earth and Planetary Science Letters, v. 209, p. 197-214.

Burbank, D.W., Leland, J., Fielding, E., Anderson, R.S., Brozovic, N., Reid, M.R., and Duncan, C., 1996, Bedrock incision, rock uplift and threshold hillslopes in the northwestern Himalayas: Nature, v. 379, p. 505-510.

Chapron, E., 1999, Contrôle climatique et tectonique de la sédimentation lacustre dans l'avantpays alpin (lac du Bourget) durant le Quaternaire récent [Ph.D. Thesis]: Université de Savoie, Géologie Alpine, Mémoire Hors Serie, no. 30, 258 p.

Finlayson, D.P., Montgomery, D.R., and Hallet, B., 2002, Spatial coincidence of rapid inferred erosion with young metamorphic massifs in the Himalayas: Geology, v. 30, p. 219222.

Gasparini N.M., Tucker, G.E., and Bras R.L., 1999, Downstream fining through selective particle sorting in a equilibrium drainage network: Geology, v.27, p. 1079-1082

Gautier, E., 1992, Recherche sur la morphologie et la dynamique fluviale dans le bassin du Buëch [Ph.D. Thesis]: Université Paris X-Nanterres, 434 p. 
Goguel, J., 1954, Une capture subactuelle dans les Hautes Alpes : Compte Rendu Sommaire de la Société Géologique de France, p181-182.

Hack, J. T., 1957, Studies of longitudinal stream profiles in Virginia and Maryland: United States Geological Survey Professional Paper, v. 294-B, p. 45-97.

Hancock, G.S., and Anderson, R.S., 2002, Numerical modeling of fluvial strath-terrace formation in response to oscillating climate: Geological Society of America Bulletin, v. 114, p. $1131-1142$

Harbor, D.J., 1998, Dynamic equilibrium between an active uplift and the Sevier River, Utah: Journal of Geology, v. 106, p. 181-194.

Howard, A.D., 1980, Thresholds in river regimes, in Coates, D.R., and Vitek, J.D. eds., Thresholds in Geomorphology: Allen and Unwin, Winchester, Massachusetts, p. 227-258.

Howard, A.D., 1998, Long profile development of bedrock channels: interaction of weathering, mass wasting, bed erosion, and sediment transport, in Tinkler K., and Wohl E.E. eds., Rivers Over Rock: Fluvial Processes in Bedrock Channels : American Geophysical Union, Washington D.C, p. 297-319.

Howard, A.D., and Kerby, G., 1983, Channel changes in badlands: Geological Society of America Bulletin, v. 94, p. 739-752.

Howard, A.D., Dietrich, W.E., and Seidl, M.A., 1994, Modeling fluvial erosion on regional to continental scales: Journal of Geophysical Research, v. 99, p. 13971-13986.

Jouanne, F., Génaudau, N., Ménard, G., and Darmendrail, X., 1998, Estimating present-day displacement fields and tectonic deformation in active mountain belts: an example from the Chartreuse Massif and the southern Jura Mountains, western Alps: Tectonophysics, v. 296, p. 403-419. 
Kirby, E., and Whipple, K.X., 2001, Quantifying differential rock-uplift rates via stream profile analysis: Geology, v. 29, p. 415-418.

Landon, N., 1999, L'évolution contemporaine du profil en long des affluents du Rhône moyen

- Constat régional et analyse d'un hydrosystème complexe, la Drôme [PhD thesis]: Université Paris IV - Sorbonne, 2 volumes, 734 p.

Lavé, J., and Avouac, J.-P., 2001, Fluvial incision and tectonic uplift across the Himalayas of central Nepal, Journal of Geophysical Research, v. 106, p. 25561-25593.

Leopold L.B, and Maddock T., 1953, Hydraulic geometry of stream channels and some physiographic implications: United States Geological Survey Professional Paper, v. 252, 57 p.

Mackin J.H., 1937, Erosional history of the Big Horn basin, Wyoming: Geolocical Society of America Bulletin, v. 48, p. 813-894.

Mandier, P., 1984, Signification dynamique et climatique des formations et terrasses fluviatiles Quaternaires dans les Alpes et leur périphérie: Bulletin de l'Association Française pour l'Etude du Quaternaire, no. 1984(1-3), p. 113-118.

Mandier, P., 1988, Le relief de la moyenne vallée du Rhône au Tertiaire et au Quaternaire. Essai de synthèse paléogéographique: Documents du BRGM, no.151, 3 volumes, 865 p.

Martinod, J., Jouanne, F., Taverna, J., Ménard, G., Gamond, J.F., Darmendrail, X., Notter J.C., and Basile, C., 1996, Present-day deformation of the Dauphiné (SE France) Alpine and Subalpine massifs : Geophysical Journal International, v.127, p. 189-200.

Montjuvent, G., 1973, La transfluence Durance-Isère : Essai de synthèse du Quaternaire du bassin du Drac (Alpes françaises): Géologie Alpine, v. 49, p. 57-118.

Montjuvent, G., 1978, Le Drac. Morphologie, stratigraphie et chronologie quaternaires d'un bassin alpin: Comité National de la Recherche Scientifique, Paris, 433 p. 
Pazzaglia, F. J., and Brandon, M. T., 2001, A fluvial record of long-term steady-state uplift and erosion across the Cascadia forearc high, western Washington State: American Journal of Science, v. 301, p. 385-431.

Pazzaglia, F.J., Gardner, T.W., and Merritts, D.J., 1998, Bedrock fluvial incision and longitudinal profile development over geologic time scales determined by fluvial terraces, in Tinkler, K., Wohl E.E., Rivers Over Rock: Fluvial Processes in Bedrock Channels: American Geophysical Union, Washington D.C, p. 207-235.

Personius, S.F., 1995, Late Quaternary stream incision and uplift in the forearc of the Cascadia subduction zone, western Oregon: Journal of Geophysical Research, v. 100, p. 20193-20210.

Roe, G.H., Montgomery, D.R., and Hallett, B., 2002, Effects of orographic precipitation variations on the concavity of steady-state river profiles: Geology, v. 30, p.143-146.

Rosique, T., 1996, Morphogénèse et évolution des paléoenvironnements alpins de la fin des temps glaciaires au début de l'Holocène [Ph.D. Thesis]: Université d'Aix-Marseille I, 288 p.

Schmid, S. M., and Kissling, E., 2000, The arc of the western Alps in the light of geophysical data on deep crustal structure: Tectonics, v. 19, p. 62-85.

Seward, D., Ford, M., Bürgisser, J., Lickorish, H., Williams, E.A., and Meckel, L.D., 1999, Preliminary results of fission-track analyses in the southern Pelvoux area, SE France, in Gosso G., Jadoul F., Sella M., and Spalla, M.I., eds., $3^{\text {rd }}$ Workshop on Alpine Geological Studies: Memorie di Scienze Geologiche, v. 51, p. 25-31.

Sklar, L., and Dietrich, W.E., 1998, River longitudinal profiles and bedrock incision models: stream power and the influence of sediment supply, in Tinkler, K., Wohl, E.E., eds., Rivers Over Rock: Fluvial Processes in Bedrock Channels: American Geophysical Union, Washington D.C, p. 237-260. 
Sklar, L., and Dietrich, W.E. 2001, Sediment and rock strength controls on river incision into bedrock, Geology, v. 29, p. 1087-1090.

Snow, R.S., and Slingerland, R.L., 1987, Mathematical modelling of graded river profiles: Journal of Geology, v. 95, p. 15-33.

Snyder, N.P., Whipple, K.X., Tucker, G.E., and Merrits, D.J., 2000, Landscape response to tectonic forcing: Digital elevation model analysis of stream profiles in the Mendocino triple junction region, northern California: Geological Society of America Bulletin, v. 112, p. 12501263.

Snyder, N.P., Whipple, K.X., Tucker, G.E., and, Merrits D.J., 2003a, Channel response to tectonic forcing: field analysis of stream morphology and hydrology in the Mendocino triple junction region, northern California: Geomorphology, v. 1315, p1-31.

Snyder, N.P., Whipple, K.X., Tucker, G.E., and Merrits, D.J., 2003b, Importance of a stochastic distribution of floods and erosion thresholds in the bedrock river incision problem: Journal of Geophysical Research, 108 (B2), 2117, doi: 10.1029/2001JB001655.

Stock, J., and Dietrich, W.E., 2003, Valley incision by debris flows: Evidence of a topographic signature: Water Resources Research, v. 39, p. 1089, doi: 10.1029 /2001WR001057.

Stock, J.D., and Montgomery, D.R., 1999, Geologic constraints on bedrock river incision using the stream power law: Journal of Geophysical Research, v. 104, p. 4983-4993.

Talling, P.J., and Sowter, M.F., 1998, Erosion, deposition and basin-wide variations in stream power and bed shear stress: Basin Research, v. 10, p. 87-108.

Tomkin, J.H., Brandon, M.T., Pazzaglia, F.J., Barbour, J.R., and Willett, S.D., 2003, Quantitative testing of bedrock incision models for the Clearwater River, NW Washington State: Journal of Geophysical Research, v. 108, 2308, doi: 10.1029/2001JB000862. 
Tricart, P., Schwartz, S., Sue, C., Poupeau, G., and Lardeaux, J.-M., 2001, La dénudation tectonique de la zone ultradauphinoise et l'inversion du front briançonnais au sud-est du Pelvoux (Alpes occidentales): une dynamique miocène à actuelle: Bulletin de la Société Géologique de France, v. 172, p. 49-58.

Tucker, G.E., and Bras, R.L., 2000, A stochastic approach to modeling the role of rainfall variability in drainage basin evolution: Water Resources Research, v. 36, p. 1953-1964.

van der Beek, P.A., and Bishop, P., 2003, Cenozoic river profile development in the Upper Lachlan catchment (SE Australia) as a test of quantitative fluvial incision models: Journal of Geophysical Research, v. 108, 2309, doi: 10.1029/2002JB002125.

Wegmann, K.W., and Pazzaglia, F.J., 2002, Holocene strath terraces, climate change, and active tectonics: the Clearwater River basin, Olympic Peninsula, Washington State: Geological Society of America Bulletin, v.114, p. 731-744.

Whipple, K.X., Hancock, G.S., and Anderson, R.S., 2000, River incision into bedrock: Mechanics and relative efficacy of plucking, abrasion and cavitation: Geological Society of America Bulletin, v. 112, p. 490-503.

Whipple, K.X., Kirby, E., and Brocklehurst, S.H., 1999, Geomorphic limits to climateinduced increases in topographic relief: Nature, v. 401, p. 39-43.

Whipple, K.X., and Tucker, G.E., 1999, Dynamics of the stream-power river incision model: Implications for height limits of mountain ranges, landscape response timescales, and research needs: Journal of Geophysical Research, v. 104, p. 17661-17674.

Whipple, K.X., and Tucker, G.E., 2002, Implications of sediment-flux dependent river incision models for landscape evolution: Journal of Geophysical Research, v. 107, 2039, doi: 10.1029/2000JB000044

Willett, S.D., Slingerland, R., and Hovius, N., 2001, Uplift, shortening and steady state topography in active mountain belts: American Journal of Science, v. 301, p. 455-485. 
Willgoose, G.R., Bras, R.L., and Rodriguez-Iturbe, I., 1991, A physically based coupled network growth and hillslope evolution model, 1, theory: Water Resources Research, v. 27, p. 1671-1684. 


\section{Figure captions}

\section{Figure 1.}

Sketch map of the Western Alps, indicating structures that have been active since the late Miocene. PF: Penninic Front; ND: Digne thrust sheet; MB: Mont Blanc Massif; Pe: Pelvoux Massif; A: Argentera Massif. Cities: Ge: Geneva; Gr: Grenoble; Ly: Lyon; Ma: Marseille; To: Torino. Box indicates study area shown in Fig. 2.

\section{Figure 2.}

Maps of the study area showing the stream network and the elements that modulate the tectonic and climatic controls on river incision. A. Shaded-relief map of the 50-m resolution DEM of the study area, with indication of glacier extents during the Last Glaciation (close hatches: MIS 2; loose hatches: MIS 4) and Pliocene to Quaternary tectonic structures: dotted lines: fold axes; black dashed lines: strike-slip faults; thick lines with triangles: major thrusts; DTS: Digne Thrust Sheet; SFT: Subalpine Frontal Thrust. B. Sketch relief of the study area with location of the rivers quoted in the text. Heavy lines refer to long profiles shown in Figs. 4 - 6. Cross pattern: crystalline rocks of the Pelvoux External Crytalline Massif (PECM); Pebble pattern: Alpine foreland; Dark grey dashed lines: mountain crests cored by resistant limestones: Tithonian in the SW of the study area; Barremian in the Vercors Massif (VE); Campanian in the Devoluy Massif (DE).

\section{Figure 3.}

Simplified log of the sedimentary cover units encountered by the non-glaciated rivers and abbreviation used in the study. Simplified stratigraphic groups used in Figs. 6 and 13: SEQ: "Sequanian" (Upper Kimmeridgian) limestone. TIT: "Tithonic" (Portlandian-Tithonian) limestone, referred to in the text as "Tithonian". HML: Hauterivian marly limestone. LCL: Lower Cretaceous (Barremian-Aptian) limestone. URG: "Urgonian" (Barremian) reef limestone. ACL: Campanian argillaceous limestone. SCL: Campanian siliceous limestone. UUCL: Undifferenciated Upper Cretaceous detrital limestone (Turonian to Coniacian). The abbreviations of Figs. 16-17 correspond to stratigraphic codes used on the BRGM (Bureau des Recherches Géologiques et Minières) 1:50,000-scale geological maps. 


\section{Figure 4.}

Logarithmic slope-distance plot of the Drac River (modified from Brocard et al., 2003). Open stars: lithogenic knickpoints. Solid star: retreating disequilibrium knickpoint. Data extracted from 1:25,000-scale topographic maps; inset shows complete plot. Best-fit linear regressions upstream and downstream of the knickpoint are: $S=0.34_{-0.13}^{+0.33} D^{-1.01 \pm 0.12}$ and $S=1.4_{-1.2}^{+7.4} D^{-1.22 \pm 0.72}$, with correlation coefficients $r^{2}=0.85$ and 0.12 , respectively.

\section{Figure 5.}

Examples of lithogenic knickpoints along small streams of the non-glaciated area. Horizontal axis: downstream distance (kilometers). Vertical axis: elevation (meters). Data extracted from the 50-m DEM. A. Céüse River; B. Maraize River; C. Gervanne River. K: knickpoints. NK: reach on resistant rock without a knickpoint. For lithological codes, see Fig.3. F: Fault. Note (1) the steep gradients of the Céüse and Maraize Rivers downstream of TIT knickpoints, sustained by the Tithonian boulders supplied to the river beds; (2) the influence of bedrock bedding dip on knickpoint generation along the Gervanne River.

\section{Figure 6.}

Long-profiles of some of the largest streams of the non-glaciated area. Thick lines with dots: data extracted from 1:25,000-scale topographic maps. Thin continuous lines: data extracted from the 50-m DEM. Thick lines: profile shape drawn manually where the profiles extracted from the DEM is too rough. Wide arrowheads: locations where drainage area reaches $30 \mathrm{~km}^{2}$. Thin vertical arrow indicates confluence of Petit Buëch and Grand Buëch rivers. Boxes with dotted pattern indicate reaches of potential knickpoint development, with an indication of bedrock composition; for lithological codes, see Fig. 3. Hatched pattern: alluvial reaches where rivers flow across sediment-filled glacial troughs. The large knickpoint in the Drôme River just downstream of $30 \mathrm{~km}^{2}$ corresponds to the historic Claps rockslide that blocked the river, leading to widespread alluviation upstream. The base of the alluvial deposits defines a smooth equilibrium profile (Brocard, 2004).

\section{Figure 7.}

Slope-area plot for the slowly incising rivers of the non-glaciated area for different bedrock lithologies (990 sites in total). Slope extracted from 1:25,000-scale topographic maps, bedrock 
from 1:50,000-scale geological maps, drainage area extracted from the 50-m DEM. Regression line is based on 631 sites located beyond the dotted vertical line that represents the critical area $\left(A_{c r}\right)$ of the detachment- to transport-limited transition in Tithonian limestone (40 $\mathrm{km}^{2}$, cf. Fig. 13). Regression parameters are listed in Table 2.

\section{Figure 8.}

A. Slope-area plot of the Buech River, distinguishing bedrock and alluvial reaches. B. Long profile and alluvial sediment thickness along the Buëch River. Sediment thickness was assessed from the compilation of field observations and archived logs of the underground data base of the Bureau des Recherches Géologiques et Minières (BRGM). Drillings are indicated with an indication of whether they reached bedrock or were stopped in alluvial sediments. T2 and T3 are fill terraces abandoned at 60 and 190 ky respectively (Brocard et al., 2003). Buëch long profile and $\mathrm{T} 2$ and $\mathrm{T} 3$ tread and strath profiles are projected onto the valley axis.

\section{Figure 9.}

Comparative plot of gradient as a function of drainage area for a rapidly incising river (Drac River), and several slowly incising rivers (Buëch, Drôme, Gervanne), showing that the concavity, slope values and scatter of slope values are higher along the rapidly incising river. $\mathrm{K}$ : disequilibrium knickpoint of the Drac River. Dashed lines: best-fit regression lines for the Drôme and Buëch rivers, and for the alluvial reach upstream of the knickpoint in the Drac River (see text for discussion). Regression parameters are listed in Table 2.

\section{Figure 10.}

Assessment of the orographic precipitation gradient in the study area. A. map of mean annual precipitation (in mm) measured at Météo-France meteorological stations (white dots) overlain on coarse DEM topography. Black arrows indicate prevailing moisture transport from the NW. B. plot of precipitation values for the Vercors stations as a function of altitude. The regression yields: Precipitation $(\mathrm{mm})=0.65 \times$ elevation $(\mathrm{m})+560$, with $r^{2}=0.74$. 


\section{Figure 11.}

Slope-area plot of the Drac and Drôme rivers after weighting the drainage areas for orographic precipitation (see text for discussion). The correction exacerbates the difference in gradient between the slowly and rapidly incising rivers; intrinsic concavities for these slope - weighted area plots are $0.39 \pm 0.08\left(r^{2}=0.44\right)$ for the Drôme River and $0.60 \pm 0.13\left(r^{2}=0.59\right)$ for the alluvial reach of the Drac River.

\section{Figure 12.}

Sketch diagram showing the location of the detachment- to transport-limited transition and the influence of bedrock strength. The equilibrium river gradient corresponds to the greater of the detachment- and transport-limited slopes. The figure assumes $\theta_{d}>\theta_{t}$. Inspired by Whipple and Tucker, 2002, Fig.1.

\section{Figure 13.}

Critical area $\left(A_{c r}\right)$ for the detachment- to transport-limited transition for some of the hardest lithological units in the study area. A. Location of the studied reaches with and without knickpoints. The drainage network is displayed in white for drainage areas larger than $2.5 \mathrm{~km}^{2}$ and in black for drainage areas larger than $38 \mathrm{~km}^{2}$. Windgaps (pentagons) and captures likely to occur in the near future (inverted triangles) are also indicated. B. Locations of knickpoints, subdued knickpoints and reaches without knickpoints, as a function of drainage area and bedrock type (see Fig. 3 for abbreviations). Dashed line: largest area for occurrence of knickpoints; Dotted line: smallest area of appearance of non-knickpoint reaches. Heavy line: weighted mean area for overlapping data.

\section{Figure 14.}

Sketch diagram of the evolution of the critical drainage area $\left(A_{c r}\right)$ with incision rate $(\dot{E})$ in the case where $\theta_{\mathrm{d}}>\theta_{\mathrm{t}}$ and $n_{d}<n_{t}$. Three different lithologies are considered and positioned according to the available field data. See text for discussion. Dots indicate that the critical area is constrained; upward and downward facing arrows indicate minimum and maximum estimates for $A_{c r}$, respectively. 


\section{Figure 15.}

Effect of bedrock lithology on the valley flat width. A. simplified lithological map of the Drôme watershed. The valley flats of the Drôme River and some of its largest tributaries are superposed where wide enough to be represented. Boxes indicate detailed topographic maps of Fig. 19. B. Downstream variations in valley-flat width along the Céans River and corresponding bedrock lithology. Boxes indicate upper and lower limits of calibrated widening rates for each lithology (cf. Figure 16; Table 3). M: marls; CM: calcareous marls, ML: marly limestones. Codes for stratigraphic units are defined in Figure 3.

\section{Figure 16.}

Examples of downstream increase of the valley-flat width in various bedrock types. The first number indicated on the straight lines is the exponent $c_{v}$ in equation (7), while the second number is the widening factor $\left(K_{v}\right)$. Dashed lines are regressions on the data, continuous lines contain $95 \%$ of the data for $c_{v}=0.4$. Some of the main types of bedrock lithologies are presented: marly limestone (panel 1); well-bedded (panel 2) and massive (panel 3) limestone; shale and marls (panel 4). Stratigraphic codes j2, j4, n1, n3 and n5 are defined in Figure 3. In panel 1, the data of the slowly incising rivers are compared to those for the rapidly incising Drac River (hatched box) for lithologically comparable stratigraphic units: the Hauterivian (n3) and Aalenian (16).

\section{Figure 17.}

Effects of varying river regime on the valley-flat width: example of the Drôme River. Comparison of the widths of the present-day valley flat with that of the $\mathrm{T} 2$ terrace level. Lines indicate some values of the ratio T2 width / current width. Lithology: for stratigraphic significance, refer to Fig. 3. J5 and n3 are rhythmic series of interbedded marly limestone and marls (n3a marlier than $\mathrm{n} 3 \mathrm{~b}$ ). $\mathrm{n} 4$ is thickly bedded limestone. The " " sign indicates that the valley flat covers several lithological units. 


\section{Figure 18.}

Examples of stream capture in detachment-limited streams (A-C) and drainage stability in transport-limited streams (D-E) in the Drôme River catchment. A and D. Detailed maps of present-day topography (contour spacing: $100 \mathrm{~m}$ ) and drainage system, extracted from the 50$\mathrm{m}$ resolution DEM. Dotted bands: Tithonian limestone. K: knickpoints, NK: reaches on Tithonian limestone without knickpoints. Dashed lines indicate direction of stream head retreat and inferred future captures. Italic numbers: drainage area in $\mathrm{km}^{2}$. Axes correspond to the Institut Géographique National Lambert III grid. Locations of these detailed maps indicated in Fig. 15. B. and E. sketch maps of inferred former drainage system and outcrop of Tithonian limestone. C. and F. sketch maps of the expected future drainage system. Grey arrows indicate migration of Tithonian limestone outcrops; black arrows expected captures. 
Table 1. Morphometric data for the three major catchments in the study area.

\begin{tabular}{lccc}
\hline & Drac River & Buëch River & Drôme River \\
\hline Length $(\mathrm{km})$ & 125 & 75 & 110 \\
Catchment area $\left(\mathrm{km}^{2}\right)$ & 2095 & 1473 & 1645 \\
Mean elevation $(\mathrm{m})$ & 1487 & 1067 & 786 \\
Maximum elevation $(\mathrm{m})$ & 3669 & 2709 & 2041 \\
Minimum elevation $(\mathrm{m})$ & 180 & 450 & 86 \\
Mean annual discharge $\left(\mathrm{m}^{3} \mathrm{~s}^{-1}\right)$ & 17 & 16 & 19 \\
$\begin{array}{l}\text { Peak discharge }- \\
\text { decadal flood }\left(\mathrm{m}^{3} \mathrm{~s}^{-1}\right)\end{array}$ & 430 & 370 & 340 \\
$\begin{array}{l}\text { Maximum measured } \\
\text { peak discharge }\left(\mathrm{m}^{3} \mathrm{~s}^{-1}\right)\end{array}$ & 700 & 557 & 556 \\
\hline
\end{tabular}

Morphometric data compiled from the Institut Géographique National 50-m resolution DEM. Discharge data from Réseau des données sur l'eau du bassin Rhône-Méditerranée-Corse (http://www.rdbrmc.com/debithydro/). Discharge stations: Drac River: Pont de Claix (125 km downstream, at confluence with Romanche River); Buëch River: Laragne (53 km downstream; upstream catchment area $1100 \mathrm{~km}^{2}$ ); Drôme River: Saillans (67 km downstream; upstream catchment area $1150 \mathrm{~km}^{2}$ ). 


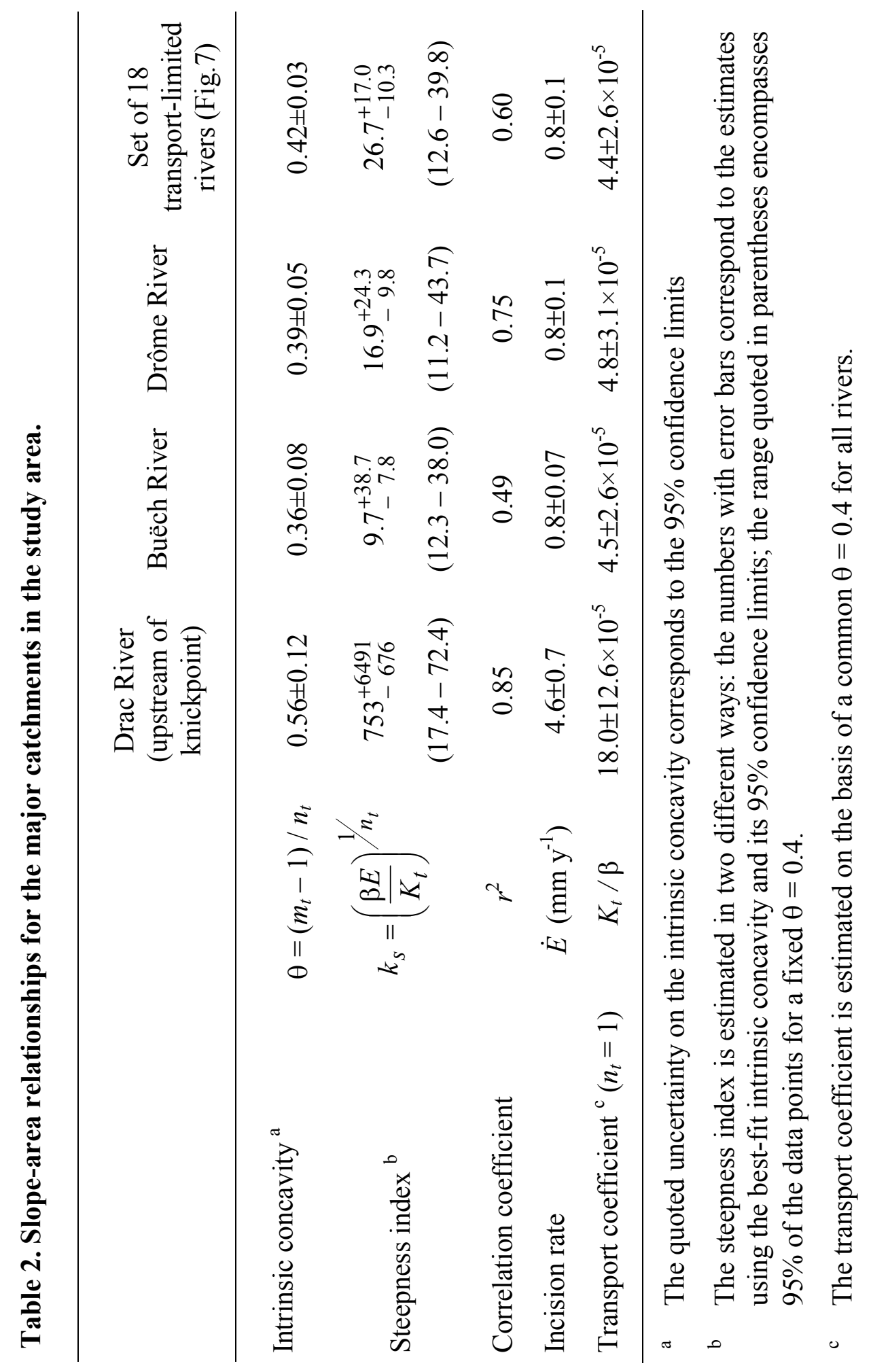


Table 3. Valley-flat width data.

\begin{tabular}{|c|c|c|c|c|c|c|}
\hline $\begin{array}{l}\text { Strat. } \\
\text { unit }\end{array}$ & lithology & $\begin{array}{l}\text { No. of } \\
\text { sites }\end{array}$ & $K_{v f}$ & $c^{*}$ & $r^{2}$ & $\begin{array}{l}\text { Range of } K_{v f} \text { for } \\
\quad c=0.4^{\#}\end{array}$ \\
\hline $\mathrm{c} 3$ & sandy limestone & 102 & 47 & $0.34 \pm 0.11$ & 0.22 & $18-130$ \\
\hline n6 & marls & 153 & 157 & $0.11 \pm 0.06$ & 0.07 & $24-135$ \\
\hline n5 & $\begin{array}{l}\text { massive } \\
\text { limestone }\end{array}$ & 55 & 41 & $0.18 \pm 0.13$ & 0.11 & $8-40$ \\
\hline $\mathrm{n} 4$ & $\begin{array}{l}\text { well-bedded } \\
\text { limestone }\end{array}$ & 152 & 47 & $0.21 \pm 0.07$ & 0.14 & $10-75$ \\
\hline n3 & marly limestone & 565 & 28 & $0.41 \pm 0.03$ & 0.61 & $10-100$ \\
\hline $\mathrm{n} 2$ & marls & 226 & 63 & $0.29 \pm 0.07$ & 0.29 & $12-100$ \\
\hline n1 & $\begin{array}{l}\text { well-bedded } \\
\text { limestone }\end{array}$ & 118 & 21 & $0.40 \pm 0.07$ & 0.42 & $8-75$ \\
\hline j6 & limestone & 22 & 41 & $0.18 \pm 0.21$ & 0.08 & $5-38$ \\
\hline j5 & limestone & 47 & 54 & $0.18 \pm 0.12$ & 0.12 & $4-42$ \\
\hline $\mathrm{j} 2-\mathrm{j} 4$ & black shales & 835 & 111 & $0.31 \pm 0.03$ & 0.46 & $25-160$ \\
\hline
\end{tabular}

* Value of the exponent $c$ in Eq. (7) with 95\% confidence interval and $K_{v f}$ calculated by regressions on the dataset for some of the most common rock units of the field area.

\# Lower and upper values of the $K_{v f}$ factor bracketing the valley-width dataset for the same rock units, taking an exponent $c=0.4$ for the drainage area dependency. 


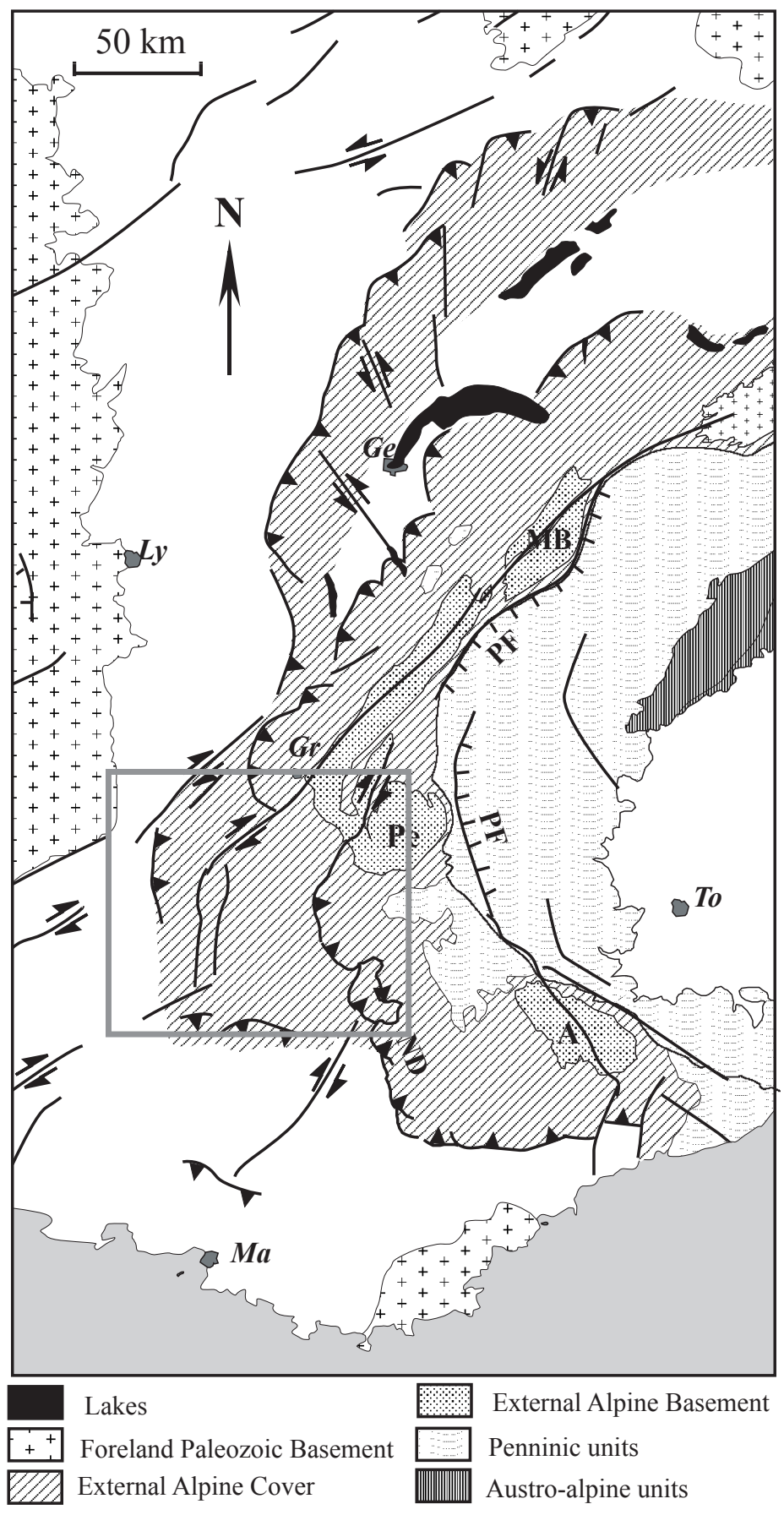

Figure 1 

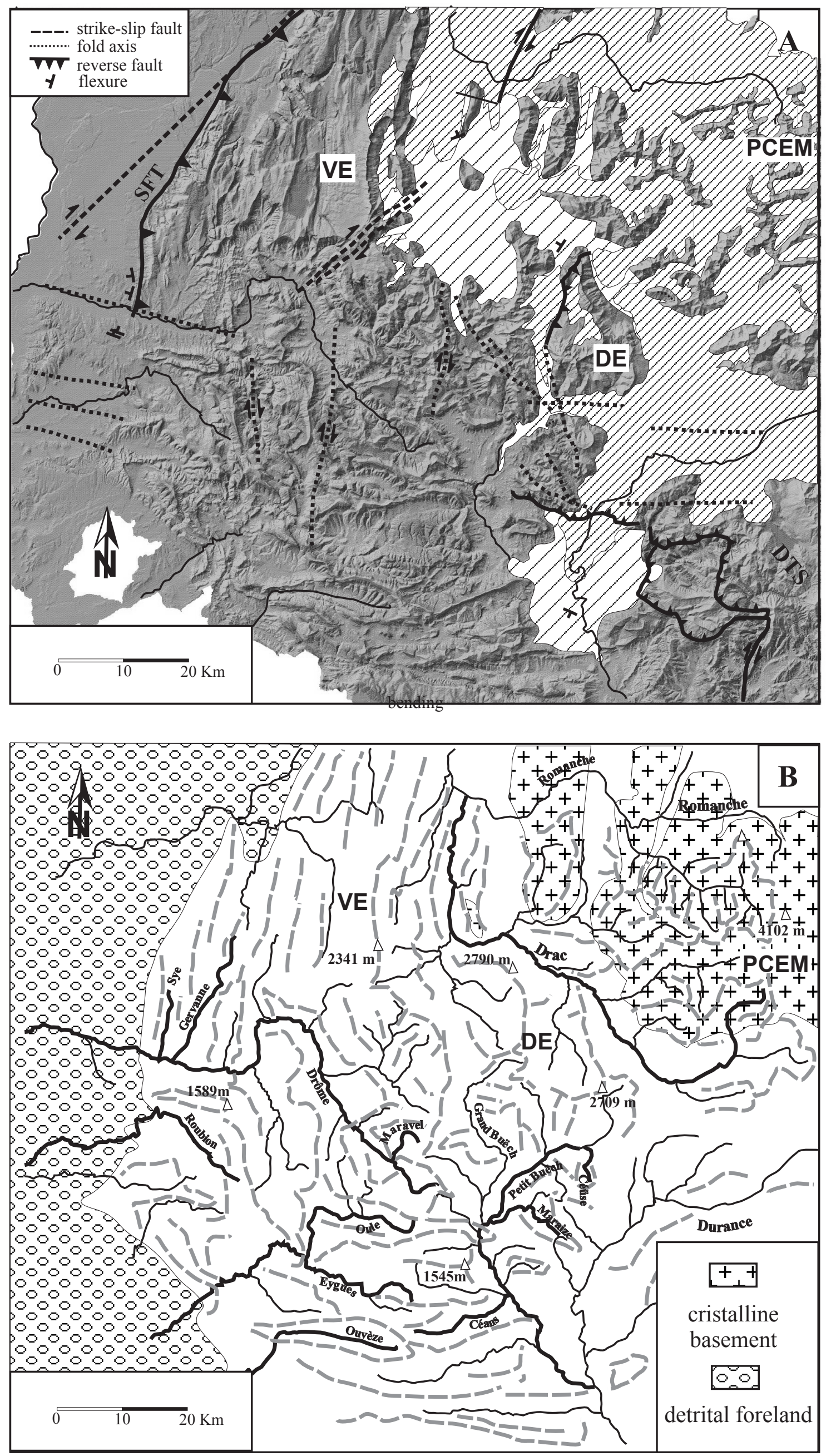


\begin{tabular}{|c|c|c|c|c|c|}
\hline stratigraphy & $\begin{array}{l}\text { Figs. } \\
15-17\end{array}$ & $\log$ & $\begin{array}{l}\text { Figs. } 6 \\
\text { and } 13\end{array}$ & & lithology \\
\hline $\begin{array}{c}\text { Campanian } \\
- \\
\text { Turonian }\end{array}$ & \multirow{7}{*}{$\begin{array}{c}\mathrm{n} 5 \\
\mathrm{n} 4 \\
\mathrm{n} 3 \mathrm{~b} \\
\mathrm{n} 3 \mathrm{a} \\
\mathrm{n} 2 \mathrm{~b} \\
\mathrm{n} 2 \mathrm{a}\end{array}-$} & 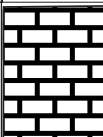 & \multirow{5}{*}{-URG } & & \\
\hline Cenomanian & & 臣点 & & & \\
\hline Albian & & & & & \\
\hline Aptian & & & & & \\
\hline Barremian & & 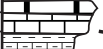 & & & \\
\hline Hauterivian & & 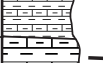 & HMI & 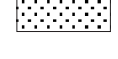 & sandstones \\
\hline Valanginian & & 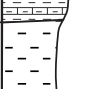 & & 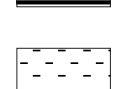 & marls and marly limestones \\
\hline Berriasian & $\mathrm{n} 1$ & 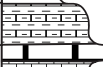 & -TIT & $=1-I=1$ & morls ond limestones \\
\hline Kimmeridgian & j6 & 蹄 & - SEO & $=-1-1-1$ & marls and limestones \\
\hline & j5 & 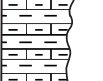 & & 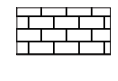 & limestones \\
\hline Oxfordian & j4 & 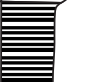 & & عب1 & massive limestones \\
\hline Callovian & $\begin{array}{c}\mathrm{j} 2 \\
\mathrm{j} 1 \mathrm{~b}\end{array}$ & 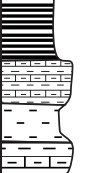 & $L_{0}$ & & \\
\hline
\end{tabular}

Figure 3

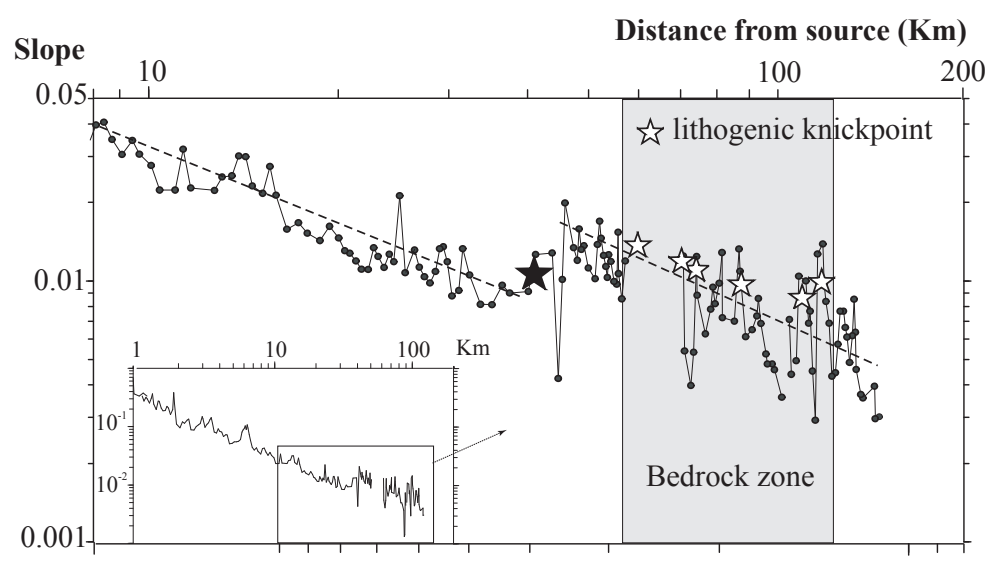

Figure 4 

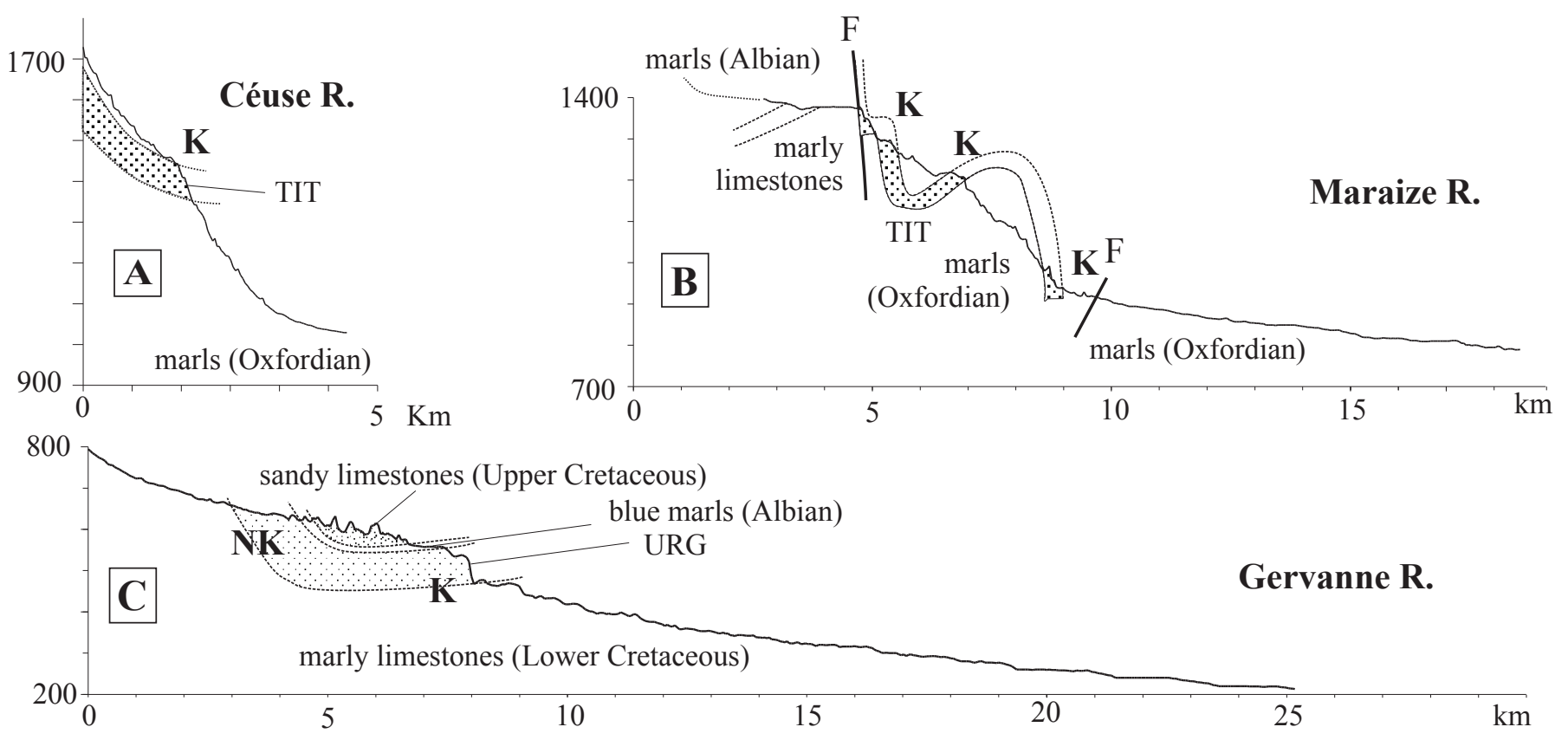

Figure 5

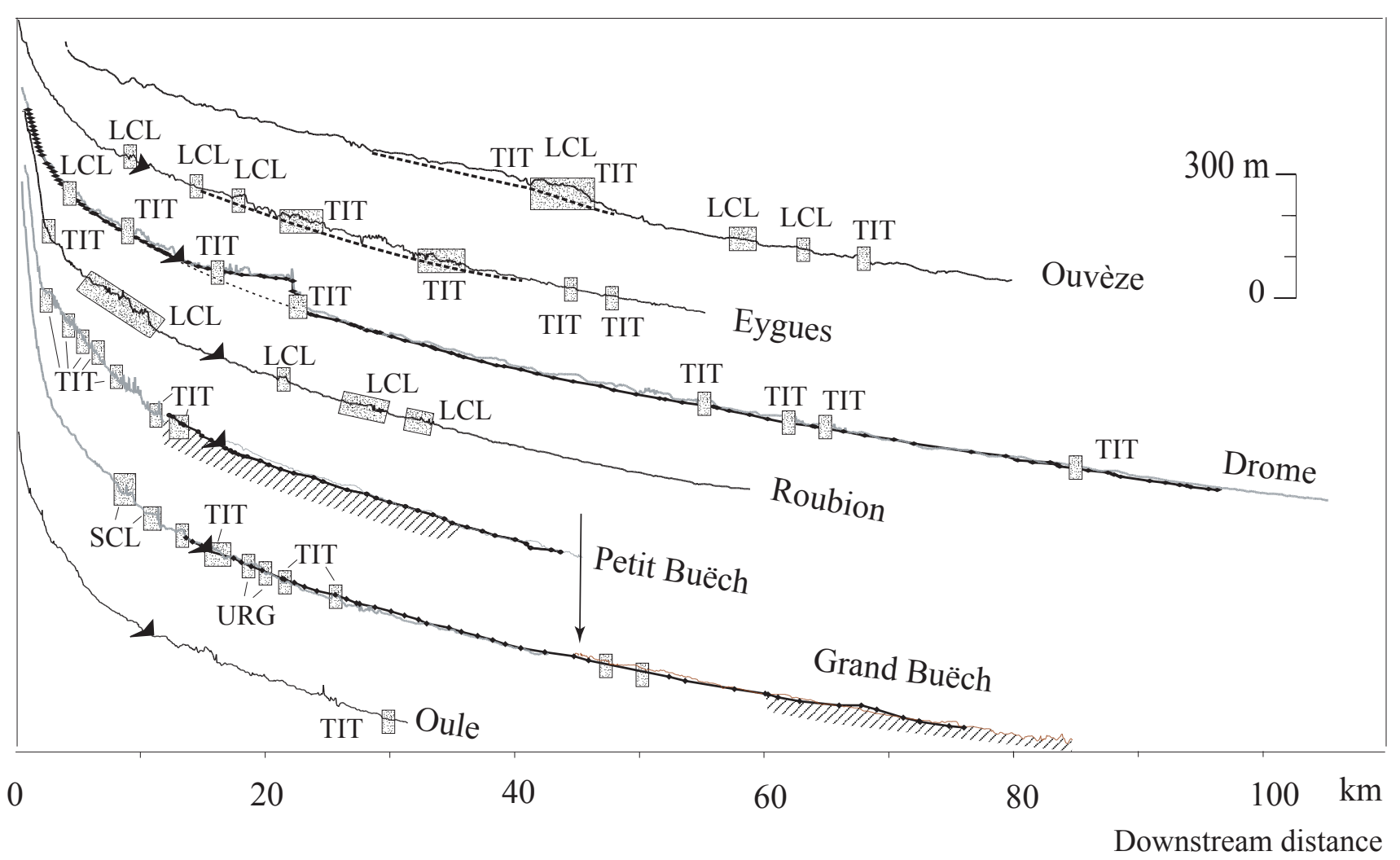

Figure 6 


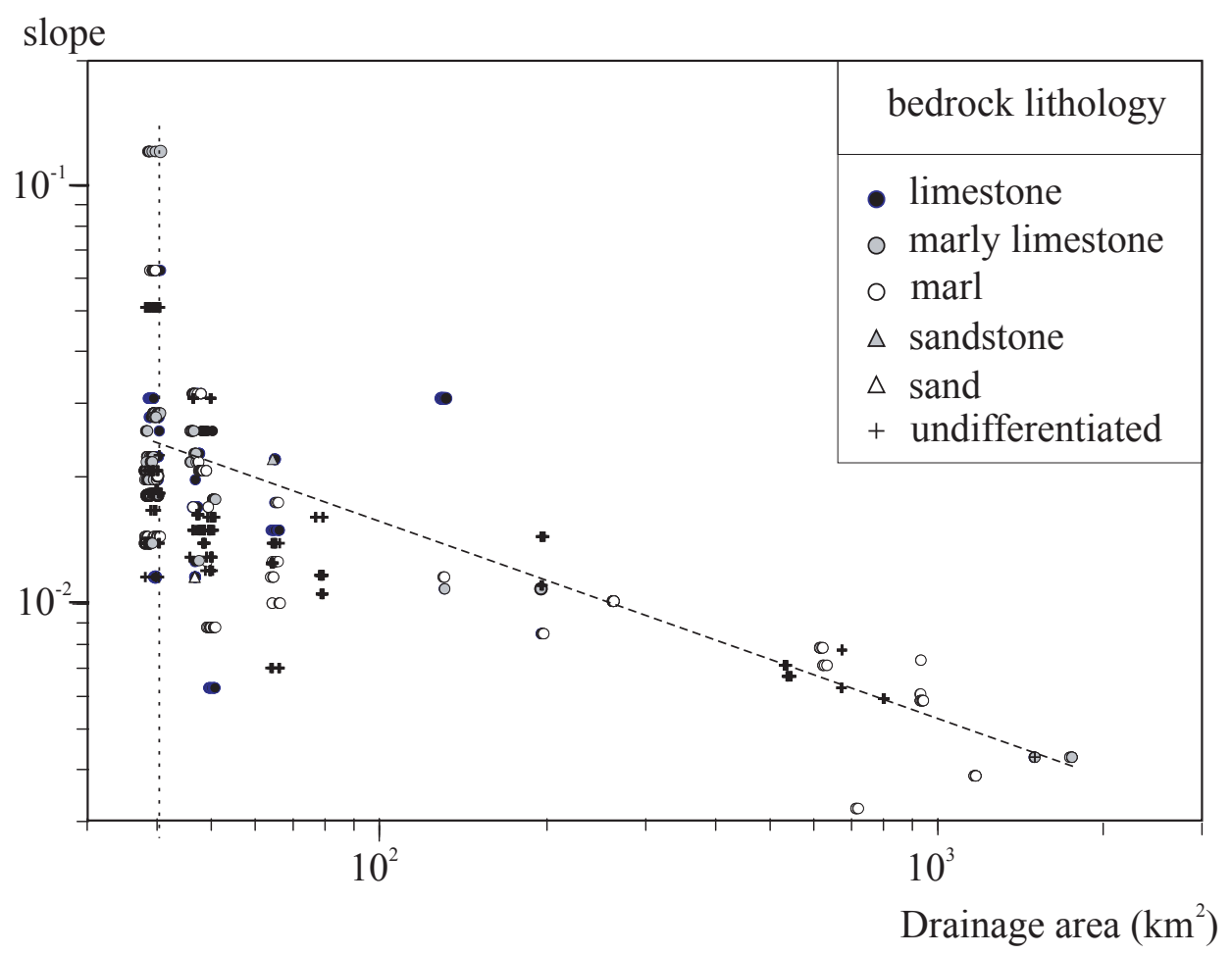

Figure 7

slope

10

Elevation (m)

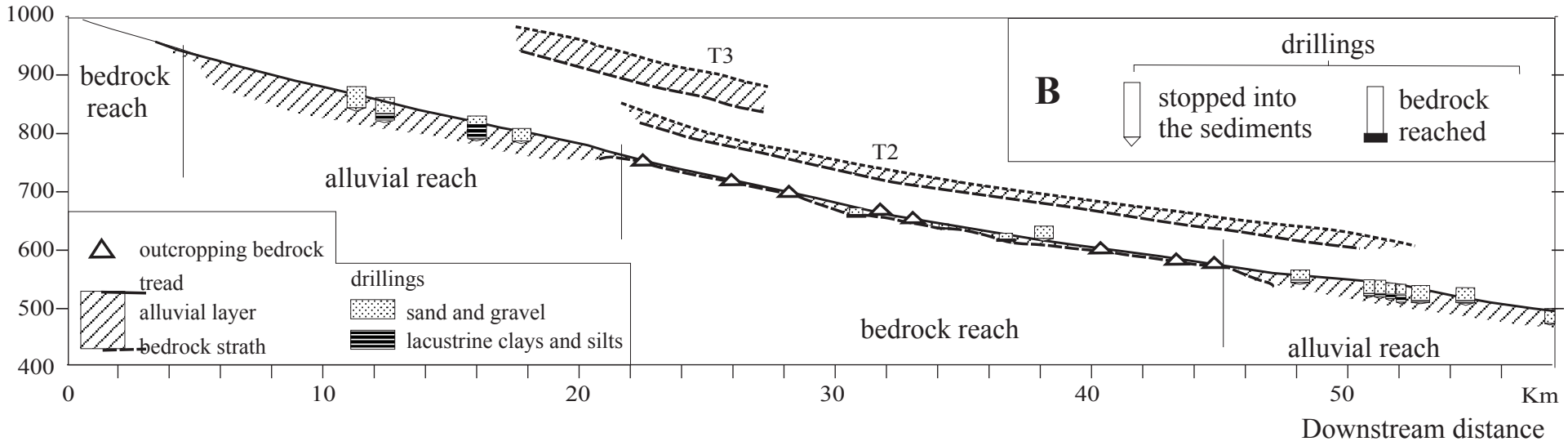

Figure 8 


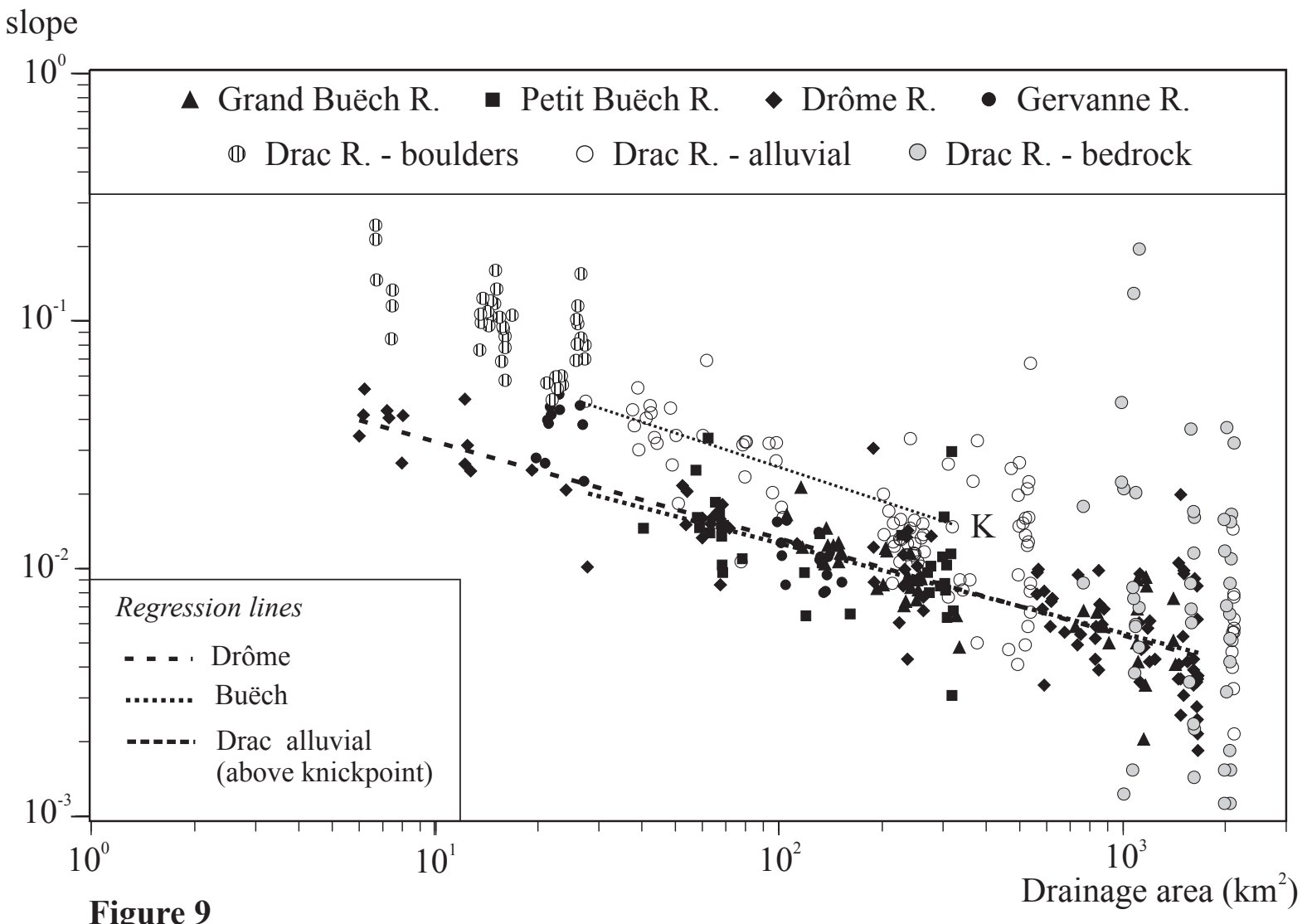

Figure 9

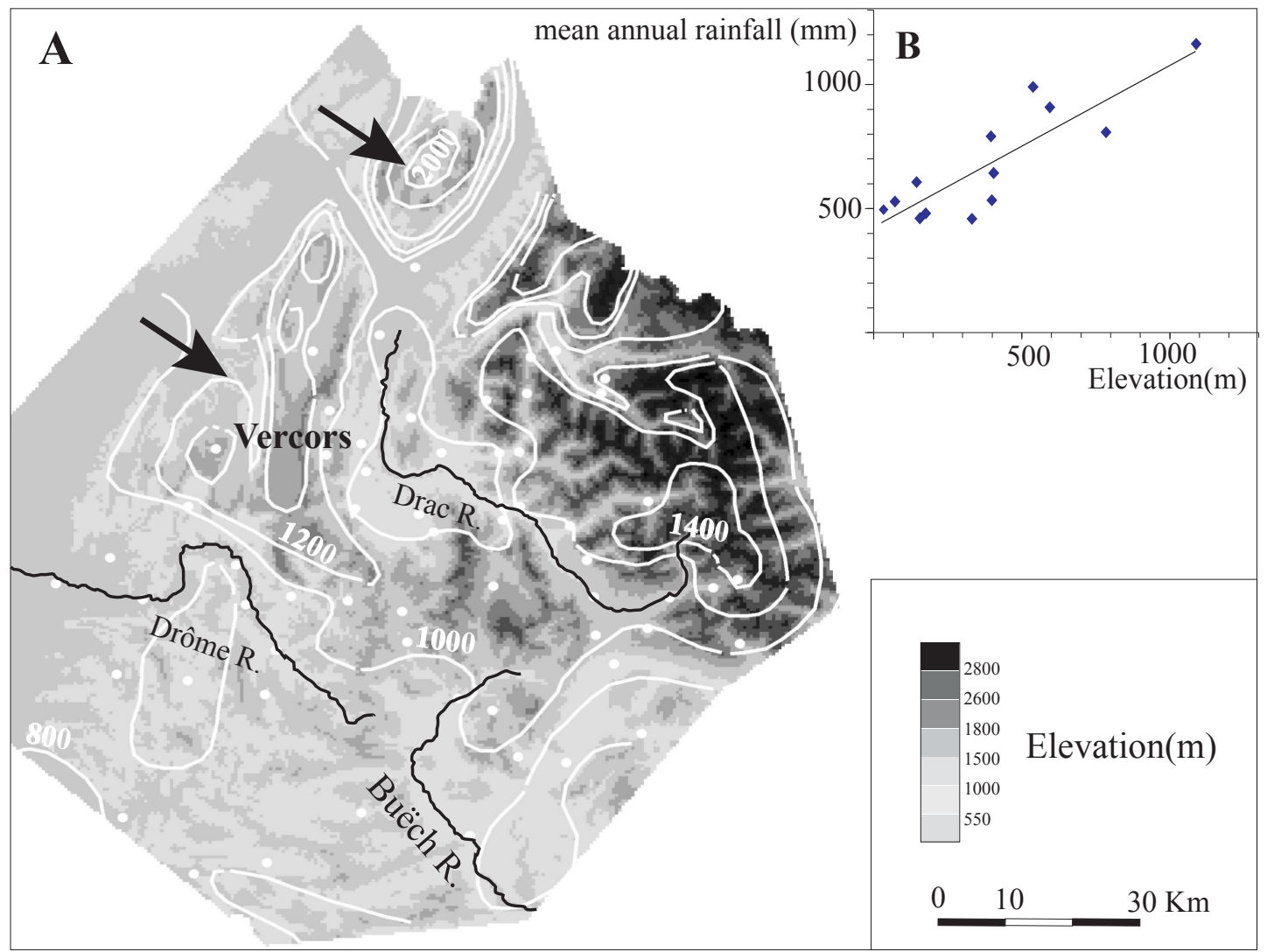

Figure 10 


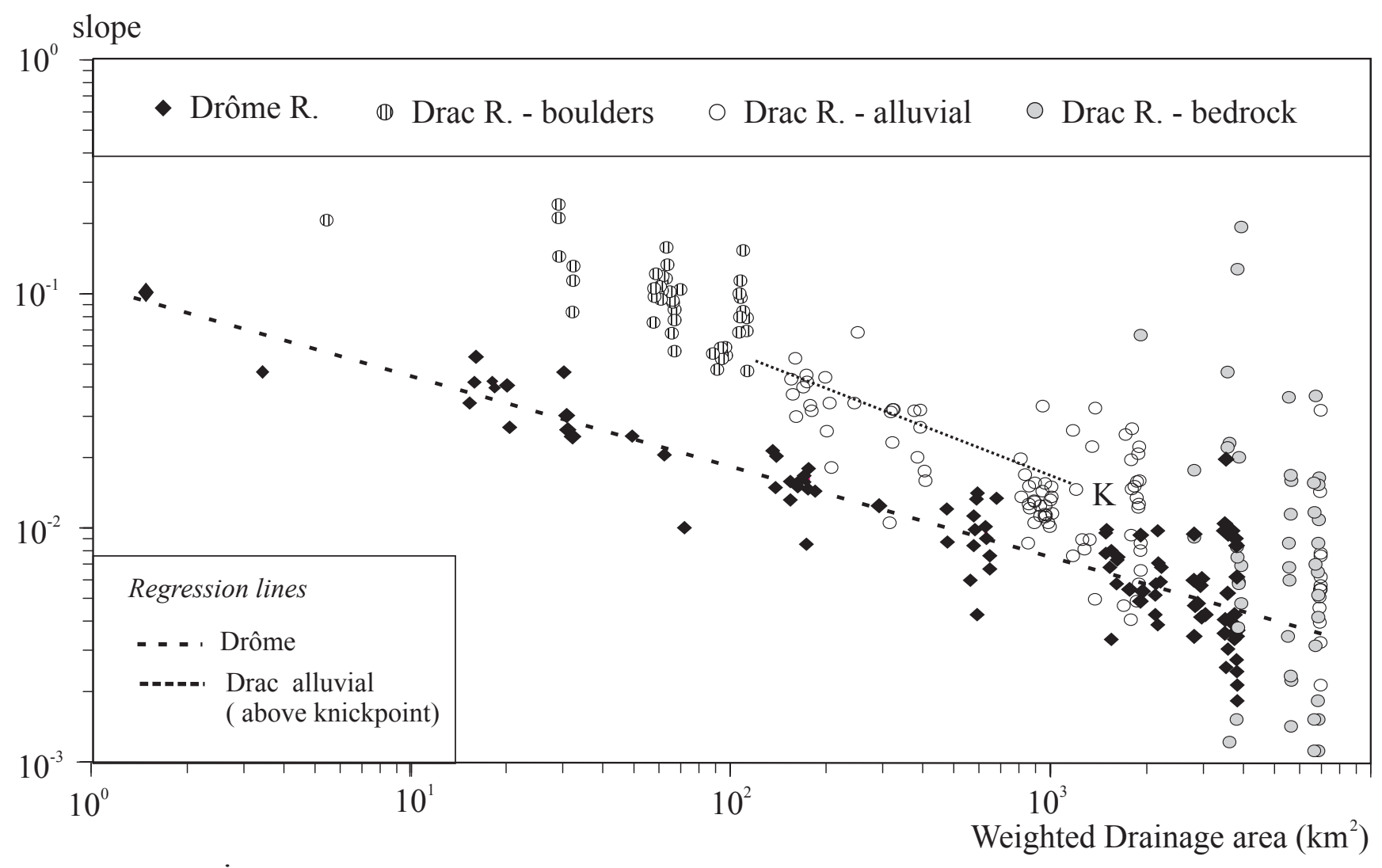

Figure 11

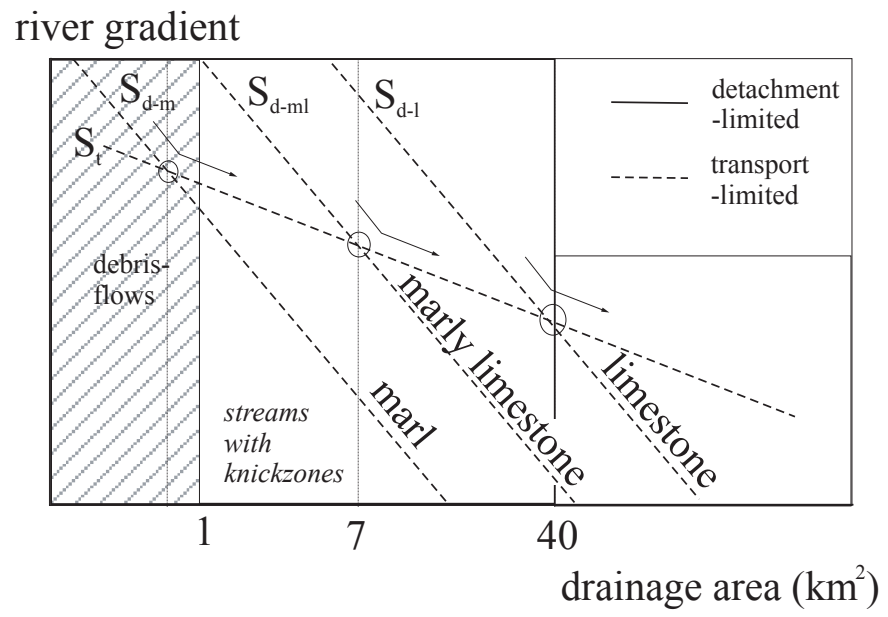

Figure 12 

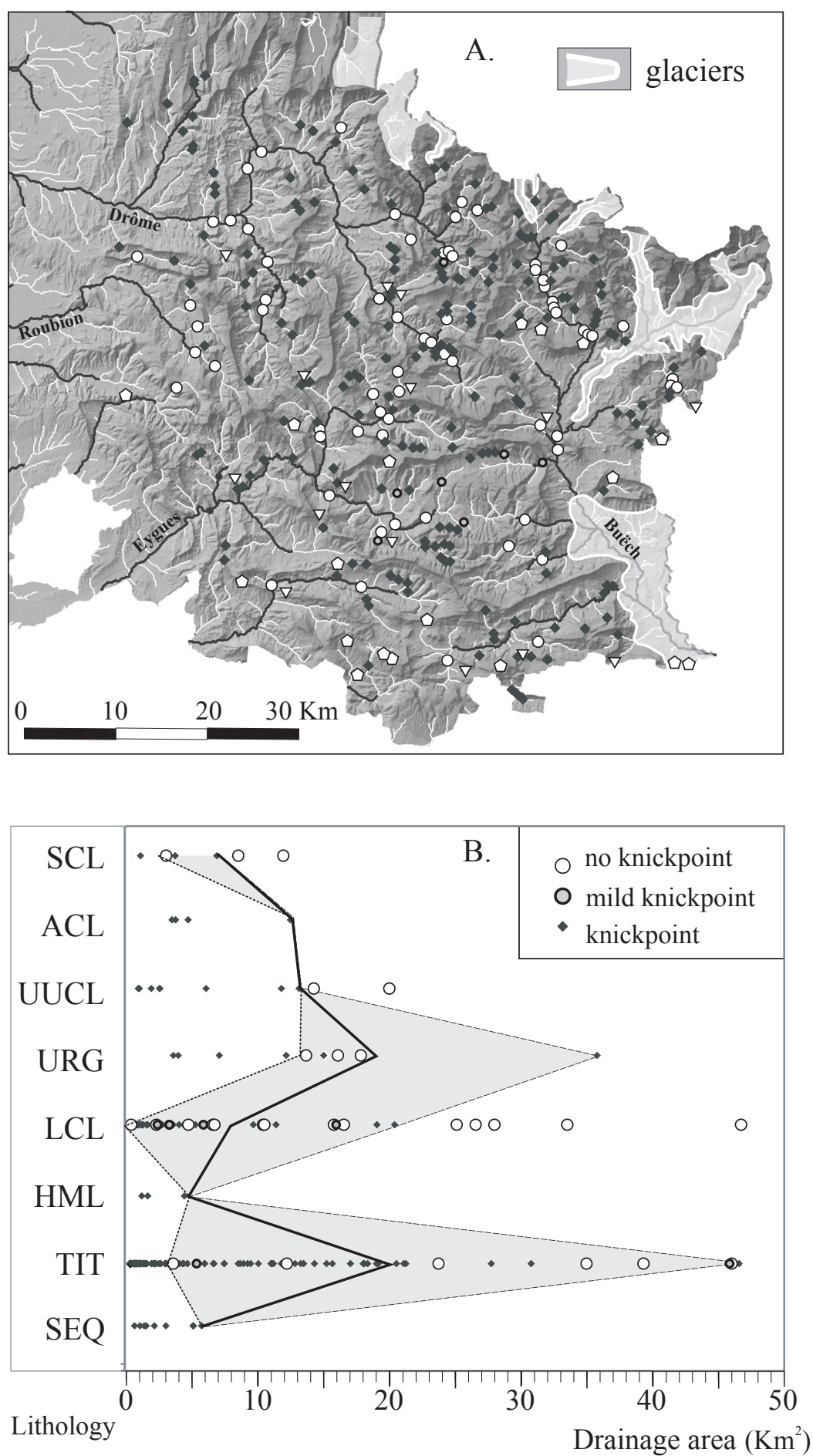

Figure 13 


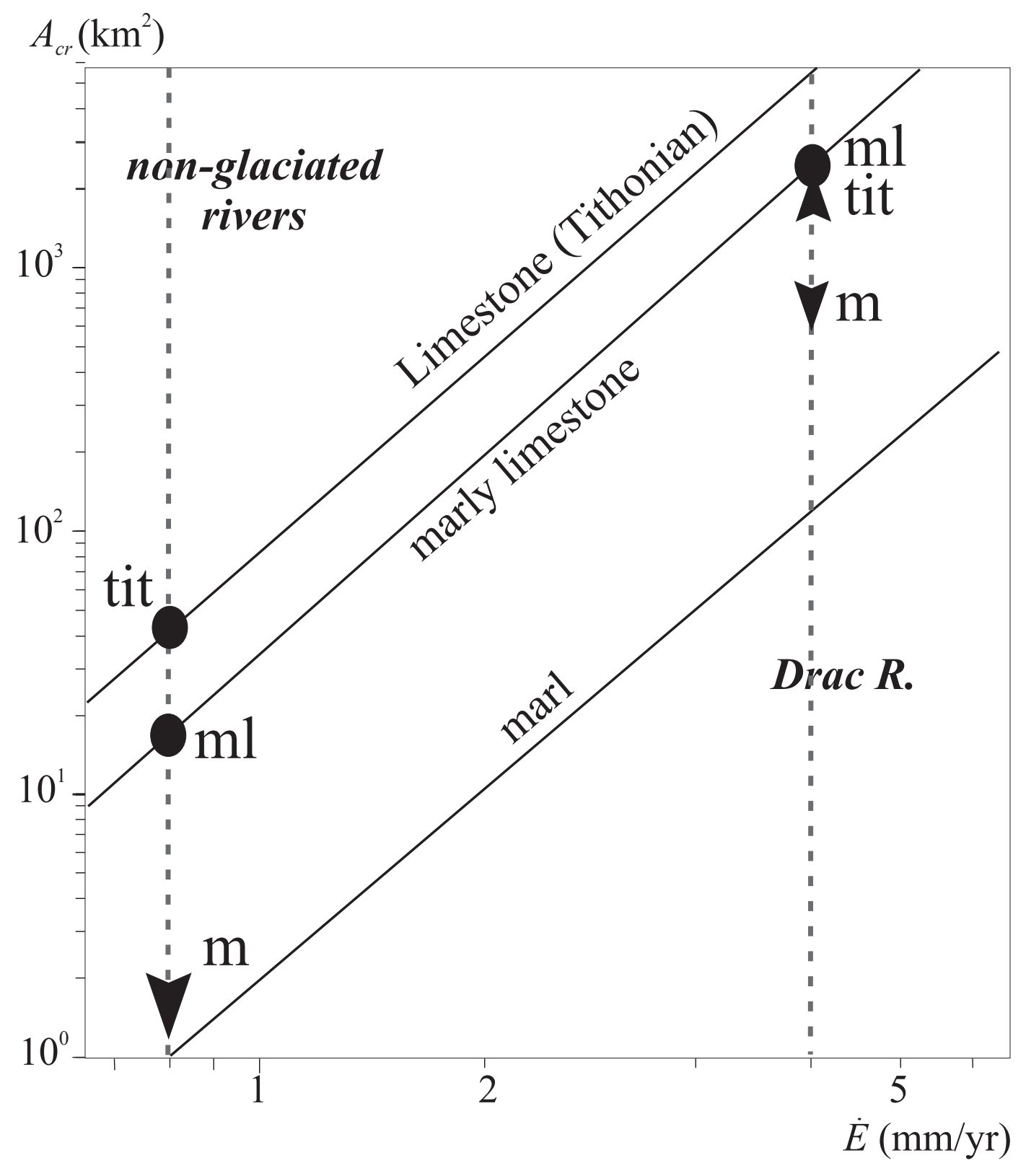

Figure 14 


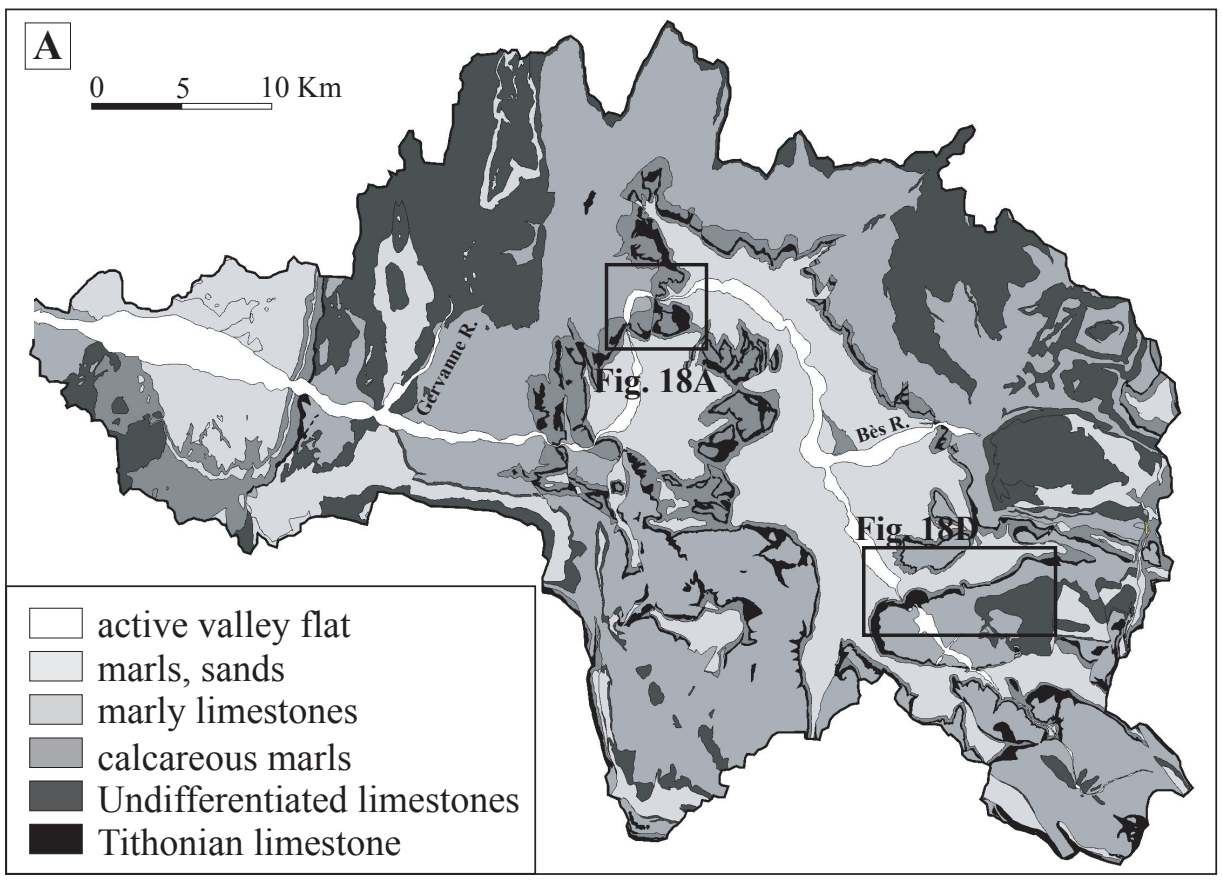

valley-flat width (m)

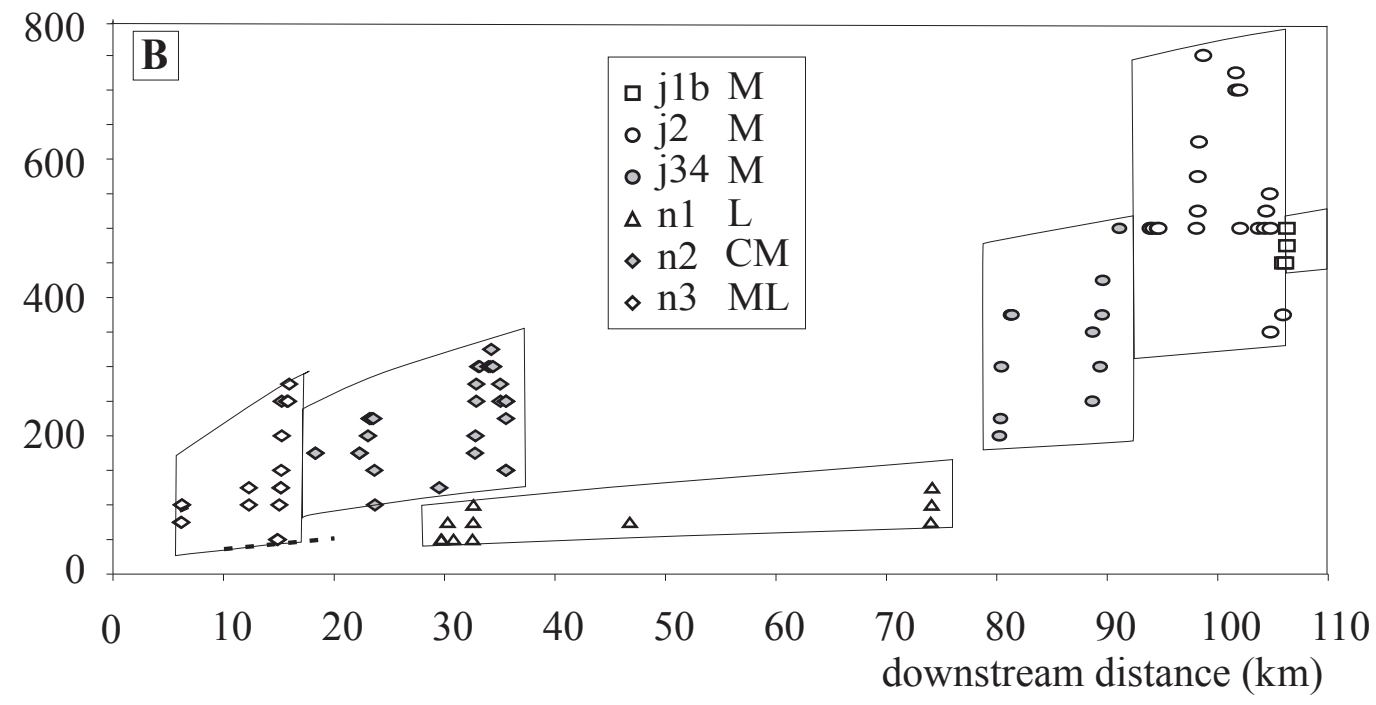

Figure 15 
Valley-flat width (m)
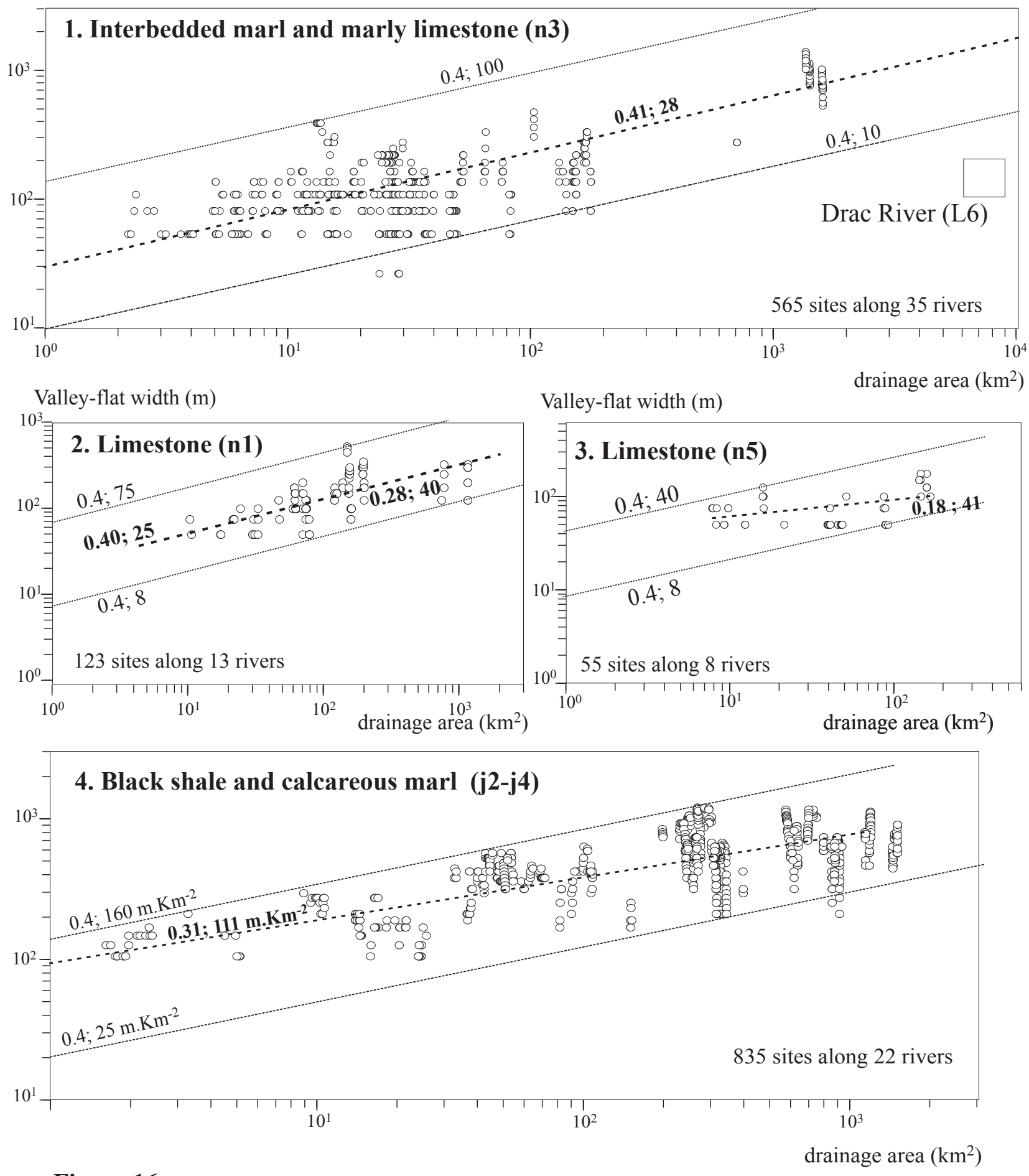

Figure 16

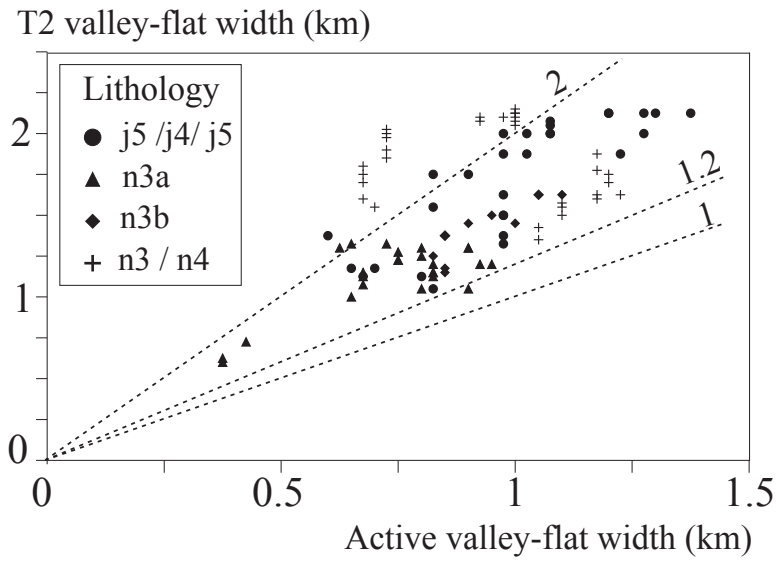

Figure 17 

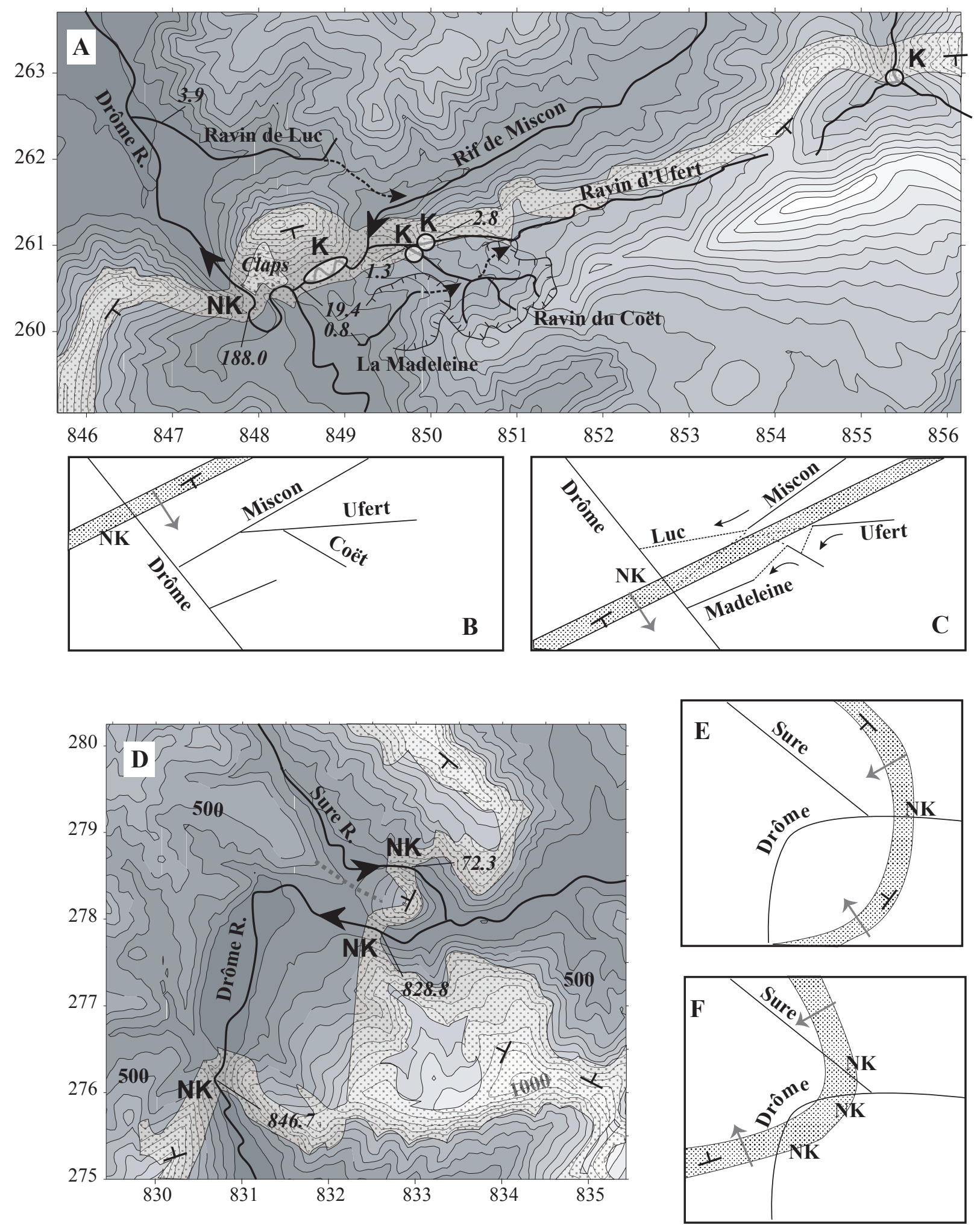

Figure 18 